
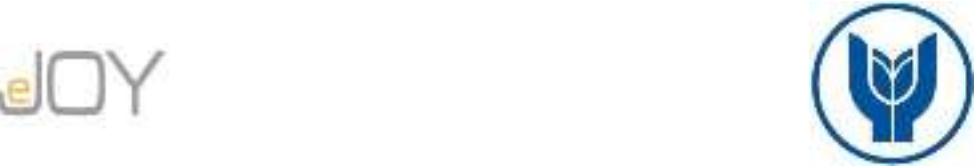

Ercan, F., Köşker, H., Albuz, N. / Journal of Yasar University, 2020, 15/59, 624-641

\title{
Çevrimiçi Seyahat Rezervasyonuna Yönelik Algılanan Riskin Kullanma Eğilimi Üzerine Etkisi
}

\section{The Effect of Percieved Risk About Online Travel Booking On Tendency to Use}

\author{
Fatih ERCAN, Zonguldak Bülent Ecevit Üniversitesi, Türkiye, fatih.ercan@beun.edu.tr \\ Orcid No: 0000-0001-6469-3000 \\ Hasan KÖŞKER, Zonguldak Bülent Ecevit Üniversitesi, Türkiye, hasankosker@yahoo.com \\ Orcid No: 000-0003-0662-8301 \\ Nalan ALBUZ, Zonguldak Bülent Ecevit Üniversitesi, Türkiye, nalanalbuz83@hotmail.com \\ Orcid No: 0000-0003-2111-0842
}

\begin{abstract}
Öz: Çevrimiçi seyahat rezervasyonu, son yıllarda kişiler tarafindan yaygın bir şekilde kullanılan seyahat rezervasyon yöntemi olarak dikkat çekmektedir. Turizm endüstrisindeki işletmelerin kendi internet siteleri, rezervasyon web siteleri ve çeşitli mobil seyahat rezervasyon uygulamalarını kullanarak kişiler rezervasyonlarını hızlı ve pratik bir şekilde yapabilmektedirler. Bununla birlikte, çevrimiçi seyahat rezervasyonuna yönelik algılanan riskler kişilerin kullanma eğilimini etkileyebilmektedir. Çevrimiçi seyahat rezervasyonunu kullanma eğilimi üzerinde etkili algılanan risk faktörlerinin tespiti, risk unsurlarına yönelik gerekli tedbirlerin alınması açısından önem taşımaktadır. Bu çalı̧̧manın amacı, çevrimiçi seyahat rezervasyonuna yönelik algılanan risklerin kullanma eğilimi üzerine olası etkilerini ortaya koymaktır. Araşstırma evrenini Zonguldak Bülent Ecevit Üniversitesi akademik ve idari personeli olușturmaktadır. Basit tesadüfi örnekleme yöntemiyle seçilen 355 katıllmcıdan anket tekniği kullanılarak veriler elde edilmis ve SPSS 21.0 for Windows programı kullanılarak analiz edilmişstir. 5 'li likert ölçeğinde hazırlanan anket 27 adet ifadeden oluşmaktadır ve ilgili alanyazında daha önce yapılan çalışmalar derlenerek oluşturulmuştur. Ayrıca ankette, katılltmclların demografik özellikleri ve çevrimiçi seyahat rezervasyonu kullanımlarına iilşkin betimleyici sorular yer almaktadır. Araștırma amacı doğrultusunda demografik bilgilere ilișkin betimsel analizler ile t tesi ve Anova testleri, korelasyon, regresyon analizleri gerçekleştirilmiştir. Regresyon analizi sonuçlarına göre algllanan performans riski, güvenlik riski ve sosyal risklerin kişilerin kullanma eğilimi üzerinde olumsuz etkiye sahip risk faktörleri olduğu tespit edilmiştir.
\end{abstract}

Anahtar Sözcükler: Çevrimiçi Seyahat Rezervasyonu, Algılanan Risk, Kullanma Eğilimi, Turizm Endüstrisi

JEL Siniflandirmast: Z30, Z31, Z32

Abstract: Online travel booking stands out as a widely used travel booking method by the people in recent years. People can make a booking quickly and easily by using the companies' own webpages, booking webpages and several mobile travel booking applications in tourism industry. However, percieved risks about online travel booking can affect the tendency to use of people. Determining the risk factors that are perceived as effective on the tendency to use the online travel booking is important in terms of taking the necessary measures for the risk factors. The aim of this study is to reveal the possible effects of percieved risks for online travel booking on the tendency to use. The research population is Zonguldak Bulent Ecevit University academic and administrative staff. Data were obtained by using questionnaire technique from 355 participants selected with simple random sampling method and analyzed wtih SPSS 21.0 for Windows program. There are 27 statements in the questionnaire prepared on a 5-point Likert scale and it was created by compiling the previous studies in the related literature. The questionnaire also includes descriptive questions about the demographic characteristics of the participants and their usage of online travel booking. In line with the purpose of the research, descriptive analyzes related to demographic informations and t test, Anova test, correlation and regression analyzes were performed. According to the results of the regression analysis, it was determined that the percieved performance risk, security risk and social risks are risk factors that have a negative effect on the tendency to use of people.

Keywords: Online Travel Booking, Percieved Risk, Tendency to Use, Tourism Industry

JEL Classification: Z30, Z31, Z32

\section{Giriș}

İnternet, son yıllarda kişiler arasında kullanım oranı giderek artan önemli bir bilgi iletişim aracı olarak dikkat çekmekte ve bu teknolojinin hemen her alanda kullanıldığı görülmektedir. Günümüzde, internetin en önemli kullanım alanlarından birisi de seyahat endüstrisidir (Mouakket ve Al-hawari 2012, 46). Kişiler, seyahat planlamasından rezervasyona kadar olan aşamalarda internet teknolojisinden yararlanmakta ve çevrimiçi ortamda rezervasyonlarını gerçekleştirebilmektedirler. Fakat her satın alma işleminde olduğu gibi tüketiciler çevrimiçi rezervasyonu kullanırken de bazı risklerle karşı karşıya kalmaktadırlar. Çevrimiçi ortamda tüketiciler tarafından algılanan riskler satın alma kararlarını doğrudan etkileyebilmektedir (Ozansoy Çadırcı ve Sağkaya Güngör 2018, 53).

Çevrimiçi rezervasyona yönelik algılanan risklerin kullanma eğilimi üzerine etkisine ilişkin çalışmaların son yıllarda ilgili alanyazında yoğun ilgi gördüğü, konunun farklı boyutlarda ele alındığı dikkat çekmektedir. Çevrimiçi seyahat rezervasyonuna yönelik algılanan performans, zaman, sağlık, güvenlik ve sosyal risk faktörlerinin kullanma eğilimi üzerine etkileri, demografik değişkenlere göre bu etkilerin farklılık gösterip göstermediği bu konuda yapılan

\section{Makale Gecmiși / Article History}

Başvuru Tarihi / Date of Application

Kabul Tarihi / Acceptance Date

: 29 Kasim / November 2019

: 19 Şubat / February 2020

(C) 2020 Journal of Yaşar University. Published by Yaşar University. Journal of Yaşar University is an open access journal.

There is no conflict of interest or ethical concern regarding this publication. 
araştırmaların genel çerçevesini oluşturmaktadır (Kim, Qu ve Kim 2009; Curras-Perez ve Sanchez-Garcia 2012; Amaro ve Duarte 2015; Marriott ve Williams 2018). Tüketicilerin çevrimiçi havayolu bileti satın almaya yönelik risk algılarının incelendiği çalışmada Kim, Qu ve $\operatorname{Kim}(2009,203)$, tüketicilerin algıladıkları güvenlik riskinin çevrimiçi havayolu bileti satın almada en etkili risk faktörü olduğunu ortaya koymaktadırlar. Ayrıca, çevrimiçi havayolu bileti satın almayanların, çevrimiçi ortamda satın alanlara göre risk algılarının daha fazla olduğu çalışmadan elde edilen diğer dikkat çekici bulgudur. Lin, Jones ve Westwood (2009, 804-805) tarafından, Tayvanlı tüketicilerin çevrimiçi seyahat satın almayı kullanma eğilimlerinde etkili algılanan risklerin tespitine yönelik yapılan çalışmada, güvenliğe ilişkin risk algılarının en etkili risk faktörü olduğu görülmektedir. Çevrimiçi havayolu bileti satın alma eğilimi üzerinde tüketicilerin algıladıkları risklerin etkilerinin araştırıldığı diğer bir çalışmanın (Kim, Kim ve Leong 2005, 33) sonuçları, algılanan risk faktörlerinin, tüketicilerin çevrimiçi havayolu bileti satın alma eğilimlerini olumsuz yönde etkilediğini göstermektedir.

$\mathrm{Bu}$ araştırmanın amacı, çevrimiçi seyahat rezervasyonuna yönelik algılanan risklerin kullanma eğilimi üzerine olası etkilerini ortaya koymaktır. Bununla birlikte, araştırmaya katılanların çevrimiçi seyahat rezervasyonunu kullanım durumu, sıklığı ve şeklini tespit etmek, sosyo-demografik değişkenler ve çevrimiçi seyahat rezervasyonu kullanımına ilişkin özelliklerle algılanan riskler arasındaki olası ilişkileri ortaya koyarak çıkarımlarda bulunmak, bu araştırmanın temel amacıyla birlikte ulaşılmak istenen alt amaçları oluşturmaktadır. Turizm ve seyahat endüstrisindeki işletmeler için mevcut ve potansiyel tüketicilerin çevrimiçi seyahat rezervasyonuna yönelik algıladıkları risk faktörlerinin neler olduğunun bilinmesi, bunların kullanma eğilimini ne yönde etkilediğinin anlaşılması, bu alanda daha kaliteli bir hizmet sunabilmek adına büyük önem taşımaktadır.

\section{Kavramsal Çerçeve}

\subsection{Risk ve Algılanan Risk Kavramlart}

Risk kavramı, hayatın her alanında, farklı zaman ve durumlarda karşımıza çıkabilecek olgulardan biridir. Tarihte risk kavramının kökleri Rönesans dönemine kadar dayanmakta, o dönemin şartlarında tehlikeli işlerle uğraşan gemiciler, ticaret yapanlar için bu kavram girişim ve tehlikenin bir birleşimini ifade ediyordu (Gregersen 2003, 355). İlk olarak 1940’l1 yıllarda Knight tarafından riskin ekonomik faaliyetlerin önemli bir bileşeni olarak nitelendirilmesiyle birlikte üzerinde durulmaya başlanan bu kavramın, ilerleyen dönemlerde farklı disiplinlerin araştırma konusu haline geldiği görülmektedir (Quintal, Lee ve Soutar 2010, 797). Türk Dil Kurumu tarafından risk, zarara uğrama tehlikesi, riziko olarak tanımlanmaktadır (https://www.sozluk.gov.tr). Risk kavramının tanımı bir olumsuzluğu içerisinde barındırmakta, bu olumsuzluktan da kişiler, kurumlar, toplumlar etkilenmektedir. Burada, nihai olarak riskten etkilenenler ise gene insanlardır (Pehlivan 2008, 91). Ercan Kalkan ve Deniz (2013, 44), riskin arka planında üç faktörün bileşiminin olduğunu belirtmektedirler. Bunlar; bazı olayların mümkün olduğu bir senaryo, bu senaryonun sonucunun belirsizliği ve insanların bu sonuçtan az veya çok etkilenmeleridir.

Belirli bir sosyal ortamda ve durumda, bir kişi için bazen doğal bazen de sosyal bir olayın veya olgunun yarattığı tehlike olan risk kavramı (Gregersen 2003, 356), gerçekleşebilecek olası bir olay ya da olayların içinde barındırdığı belirsizlikler ve bunun insanlarda yarattığı olumsuz etkileri göstermektedir. Bu bakımdan kişilerin olayları algılamaları, değerlendirmeleri bir risk algısını meydana getirmektedir. Yeung ve Morris (2006, 295), algılanan riski, meydana gelebilecek kayıplar ve bunların muhtemel sonuçlarının önem derecesine ilişkin kişilerin değerlendirmesi olarak tanımlamaktadırlar. Kim, Kim ve Leong (2005, 36-38), algılanan riskin, doğası gereği öznel bir olgu olduğunu, tüketicilerde öznel değerlendirmeler sonucu bir risk algısının oluştuğunu belirtmektedirler. Yazarlar ayrıca, algılanan riskin sadece kişilerin öznel risk algısı seviyesinden etkilenmediğini, alışverişte kullanılan yöntemin de etkili olduğundan bahsetmektedirler. Dolayısıyla, algılanan risk kavramının herkes için kesin, net bir tanımla kapsamının belirlenmesi güçtür. İlk kez 1960 yılında Bauer tarafından pazarlama alanyazınına giren algılanan risk kavramının, ekonomi ve finans alanlarında da karar verme teorilerinde sıklıkla kullanıldı̆̆ı görülmektedir (Souza, Silva ve Barbosa 2016, 1255).

\subsection{Algilanan Risk Boyutlart}

Tüketiciler satın alma kararı verirken çeşitli faktörleri değerlendirmekte, ihtiyacını en iyi karşılayacak şekilde kararlarını vermek istemektedirler. $\mathrm{Bu}$ düşünceden hareketle tüketiciler karar verme ve satın alma eylemlerini gerçekleştirmektedirler. Fakat verilen kararların meydana getireceği sonuçların belirsizliği ve istenmeyen sonuçlarla da karşılaşma olasılığının olması tüketicinin değişik riskler algılamasına neden olmakta, algılanan riskler birçok faktöre ve duruma göre değişkenlik gösterebilmektedir. $\mathrm{Bu}$ sebeple algılanan risk konusu ilgili alanyazında farklı boyutlarda ele alınmaktadır (Yüce 2014, 230).

Algılanan risk, bir ürün yada hizmeti tercih etme, satın alma ve kullanıp kullanmama kararı verilmesine neden olabilecek bir faktör olarak değerlendirilmekte, bu sebeple algılanan risk boyutlarının ilgili alanyazında birçok araştırmacı tarafından ele alınan bir konu olduğu belirtilmektedir (Koçoğlu 2016, 248). Jacoby ve Kaplan (1972, 2) tarafindan yapılan en eski sınıflandırmalardan birine göre ise algılanan riskler finansal, performans, fiziksel, psikolojik ve sosyal riskler olmak üzere beş gruba ayrılmaktadır. Yazarlar, bu risklerin işlevsel olarak birbirinden bağımsız olduklarını, bir risk faktöründeki artışın, diğer bir risk faktöründe artışa, azalışa neden olabileceğini ya da herhangi bir etkinin olmayabileceğini belirtmektedirler. Çevrimiçi havayolu bileti satın alma eğiliminde algılanan riskin etkisini araştırdıkları çalışmalarında Kim, Kim ve Leong $(2005,41)$ algılanan riski sosyal, zaman, finansal, performans, fiziksel, psikolojik ve güvenlik riski olarak yedi boyutta incelemektedirler. Karamustafa ve Erbaş’ın (2011, 123-125), paket turları satın alma 
karar sürecinde algılanan riskleri inceledikleri çalışmalarında fonksiyonel (performans) risk, finansal risk, zaman riski, fiziksel risk, psikolojik risk, sosyal risk ve duyusal risk şeklinde hizmet sektörü bağlamında algılanan risk boyutlarını ele aldıkları görülmektedir. Liang, Li ve Xu (2018, 646-647), çevrimiçi ortamdaki belirsizlik ve algılanan risklerin tüketicilerin satın almada bu ortamı kullanma eğilimi üzerine etkilerini inceledikleri çalışmalarında, algılanan risk kavramını finansal risk, güvenlik riski, performans riski, sosyal risk ve psikolojik risk olarak beş boyutta ele aldıkları görülmektedir.

Algılanan risk boyutları ile ilgili yapılan çalışmalar incelendiğinde, çalışmanın konusu, kapsamı ve özelliğine göre çalışmalarda kullanılan bu boyutların farklılaştığı görülmektedir. Hizmet sektörünün genel özelikleri, çevrimiçi ortamdaki hizmet ve satın alma şekli dikkate alındığında, güvenlik (gizlilik) riski, performans (kalite) riski, sağlık (fiziksel ve psikolojik) riski, zaman riski ve sosyal risk olarak algılanan riski boyutlandırmak mümkündür. Güvenlik riski, kişisel bilgilerin izinsiz kullanımı sonucu bu bilgilerin çalınma olasılığı ve gizliliğiyle ilgili risktir. Performans riski, ürünlerin hatalı üretimi, taahhüt edildiği gibi doğru ve tam işlev görmemesi, bu sebeplerle beklenen faydaları sağlayamaması olasılıklarına ve kaliteye yönelik risklerdir. Sağlık riski, çevrimiçi satın almalarda bilgisayarın uzun süreli kullanımının yorgunluğa, görme problemlerine yol açabilmesi ve çeşitli fiziksel rahatsızlıkların yanı sıra sahte, gerçek olmayan ürün ve hizmetleri satın alma kaygısının oluşturduğu psikolojik huzursuzluk ve gerginlikleri kapsamaktadır. Zaman riski, kötü bir satın alma kararı verilmesiyle araştırma, alışveriş için veya istenmeyen ürünlerin iade edilmesi, değişimine ayrılan zamanın boşa harcanmasıyla ilgili zaman kaybı riskidir. Sosyal risk, bir ürün ya da hizmetin tercih edilmesi sonucu toplumda akıl dışı, mantıksız, popülerliği düşük biri gibi görünmek, sosyal statü ve itibarın kaybedilmesi olasılığıdır (Zhang vd. 2012, 9). Tablo 1'de, Hong ve Yi (2012, 1307) tarafindan algılanan risk boyutları ve risk unsurları açıklanmaktadır.

Tablo 1. Algılanan Risk Boyutları ve Risk Unsurları

\begin{tabular}{|l|l|}
\hline Risk Boyutu & Risk Unsurları \\
\hline Güvenlik (Gizlilik) Riski & Özel bilgilerin çalınması \\
& Satın alma alışkanlarının takip edilmesi \\
& İzinsiz iletişime geçilmesi \\
& Kullanıcı hesap bilgilerinin gizliliğinin korunamaması \\
\hline Performans Riski & Orijinal olmama riski \\
& Ürün fonksiyonlarıyla ilgili riskler \\
& Ürün kalitesinin olduğundan daha fazla gösterilmesi \\
& Anlatılanlar ve gerçekte olan arasındaki olumsuz farklar \\
\hline Sağlık (Psikolojik ve Fiziksel) Riski & Psikolojik baskı \\
& İsteklerin karşılanmaması \\
& Fiziksel riskler \\
\hline Zaman Riski & Bilgi aramak için uzun zaman harcanması \\
& Teslimat zamanının belirsizliği \\
& Detaylı ödeme süreçlerinin olması \\
& Geri ödeme zamanlarının uzun olması \\
\hline Sosyal Risk & İş ve arkadaş çevresinden gelebilecek eleştiriler \\
& Aileden gelebilecek eleştiriler \\
\hline
\end{tabular}

Kaynak: Hong ve Yi 2012, 1307.

\subsection{Turizmde Çevrimiçi Rezervasyona Yönelik Algllanan Riskler}

Algılanan risk, tüketicilerin bir ürün ya da hizmeti satın alma, kullanma kararı vermesinde belirleyici bir faktördür. Burada, bir ürün ya da hizmeti kullanma ve satın alma sürecindeki belirsizlikler tüketiciler için riskin temelini oluşturmaktadır (Naiyi 2004, 177). Bununla birlikte, satın alma işleminin yapıldığı araçlar ve ortam da tüketiciler için bazı riskler oluşturabilmektedir (Kim, Kim ve Leong 2005, 38). İnternet, günümüzde en yaygın kullanılan bilgi ve iletişim aracı olmakla birlikte, ürün ve hizmetlerin aktif bir şekilde satış ve pazarlamasının yapıldığı bir mecra olarak da görülmektedir. Turizm işletmelerinde tanıtım, iletişim, satış, rezervasyon ve diğer hizmetlerin sunulmasında internet günümüzde önemli bir araç konumundadır.

Turizm endüstrisinde, turizm hizmetlerinin çevrimiçi ortamda satın alınması ve buna yönelik algılanan riskler üzerine çalışmaların, son yıllarda ilgili alanyazında önemle üzerinde durulan konulardan biri olduğu görülmektedir. Souza, Silva ve Barbosa (2016, 1253), turistik ürünlerin satın alınma sürecinin, hizmetlerde fiziksel kanıt eksikliği gibi endüstriye özgü birtakım özelliklerden dolayı oldukça riskli olduğunu belirtmekte, bu nedenle çevrimiçi ortamda turizm hizmetlerinin satın alınmasına yönelik algılanan risklerin fazla olduğundan bahsetmektedirler. İnternet teknolojilerinin günümüzde birçok alanda işletmelerin faaliyetlerini önemli derecede etkilediğini belirten Kim, Kim ve Leong (2005, 34), seyahat endüstrisinin çevrimiçi ortamda alışverişe en iyi uyum sağlayan hizmet alanlarından biri olduğunun altını çizmektedirler. Yazarlar çevrimiçi ortamda otel rezervasyonu yapma, araba kiralama ve uçak bileti satın almanın günümüzde yoğun bir şekilde gerçekleştirildiğine de dikkat çekmektedirler. 
İnternetin günümüzde kişilerin seyahat bilgisi araştırma, karar verme ve seyahatle ilgili ürün ve hizmetleri satın alma şeklini değiştirdiğini belirten Lin, Jones ve Westwood (2005, 782-783), bununla birlikte bazı tüketicilerin de yüksek maliyetler ve karmaşı seçeneklerden dolayı çevrimiçi ortamda seyahat ürünlerini satın almaya yönelik algılanan risklerinin yüksek olduğunu ve isteksiz olduklarını vurgulamaktadırlar. Amaro ve Duarte $(2013,764)$, seyahat ve turizm endüstrisinde, riskin çevrimiçi seyahat alışverişini engelleyici önemli bir faktör olduğunu ve dünya çapında bu alanda yapılan çalışmaların genelinde algılanan riskin çevrimiçi seyahat alışverişini etkileyen önemli bir unsur olarak ortaya çıktığını belirtmektedirler.

\subsection{Algılanan Risk ve Çevrimiçi Hizmetleri Kullanma Ĕgilimi İlişkisi}

Algılanan risk, tüketici satın alma sürecinin ilk aşamalarında belirleyici bir etken faktör olarak tanımlanmakta, hizmetlerin soyut olması, dayanıksızlığı gibi kendine has özellikleri turizm ve seyahat endüstrisinde çevrimiçi hizmetleri kullanmaya yönelik algılanan riski artırmaktadır (Kim, Qu ve Kim 2009, 205-207). Çevrimiçi işlemlerde algılanan risklerin tüketicilerin kullanma eğilimleri üzerindeki etkilerini araştıran farklı çalışmalar, algılanan risklerin tüketicilerin çevrimiçi işlemleri kullanma eğilimi üzerindeki olumsuz etkilerini ortaya koymaktadır. Nguyen ve Nguyen (2017, 1903), tüketicilerin algıladıkları risklerin çevrimiçi bankacılık hizmetlerini kullanma eğilimleri üzerine etkisini araştırdıkları çalışmalarında, güvenlik riski, sosyal risk, zaman riski, finansal ve performans risklerinin tüketicilerin kullanma eğilimi üzerinde olumsuz etkiye sahip risk faktörleri olduğunu ortaya koymaktadırlar. Benzer şekilde, Marafon vd. $(2018,277)$ tarafından yapılan araştırmanın sonuçları da, algılanan risklerin tüketicilerin çevrimiçi bankacılık hizmetlerini kullanma eğilimi üzerinde olumsuz yönde etkili olduğunu göstermektedir.

Dönmez Genç $(2017,24)$, turizmde çevrimiçi rezervasyon işlemlerinin güvenlik bakımından riskli ve erişimin kısıtlı olduğu durumların tüketicilerin kullanma eğilimini olumsuz yönde etkileyeceğini belirtmektedir. Yazar, güvenlik ve erişim dışında turizmde çevrimiçi rezervasyonun tercih edilmeme nedenlerini şu şekilde açıklamaktadır:

- Çevrimiçi rezervasyon süreçlerine yönelik acemilik ya da bu süreçlerin tüketiciler tarafindan hiç bilinmemesi,

- Tüketicilerin kullandıkları bir kredi kartının bulunmaması,

- Tüketicilerin geleneksel yüz yüze iletişimi tercih etmeleri,

- Çevrimiçi rezervasyon süreçleri ve işletmelere duyulan güven eksiliği,

- Kişisel bilgilerin çevrimiçi ortamda paylaşılmak istenmemesi.

Çevrimiçi ortamda yapılan rezervasyon işlemlerinde algılanan risk faktörleri tüketicilerin bu hizmetleri kullanma eğilimini etkileyebilmektedir. Bu bakımdan, turizmde çevrimiçi seyahat rezervasyonuna yönelik algılanan riskler ve bunların kullanma eğilimi üzerine etkilerinin anlaşılması turizm işletmeleri açısından önem taşıyan bir konu olarak dikkat çekmektedir.

\section{Yöntem}

$\mathrm{Bu}$ araştırmanın amacı, çevrimiçi seyahat rezervasyonuna yönelik tüketiciler tarafindan algılanan risklerin kullanma eğilimi üzerine olası etkilerini araştırmaktır. Tüketicilerin çevrimiçi seyahat rezervasyonuna yönelik algıladıkları risklerin tespit edilmesi, turizm ve seyahat endüstrisindeki işletmelerin bu riskleri en az düzeye indirmeleri, çevrimiçi rezervasyonu daha fazla kişinin kullanmasını sağlamaları ve daha fazla kişiye erişebilmeleri açısından önem taşımaktadır. Araştırma amacı doğrultusunda hipotezler şu şekilde oluşturulmuştur:

Hı: Çevrimiçi seyahat rezervasyonuna yönelik algılanan güvenlik riski kullanma eğilimi üzerinde anlamlı ve olumsuz etkiye sahiptir.

$\mathbf{H}_{2}$ : Çevrimiçi seyahat rezervasyonuna yönelik algılanan performans riski kullanma eğilimi üzerinde anlamlı ve olumsuz etkiye sahiptir.

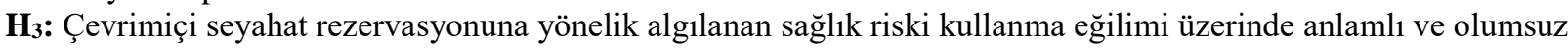
etkiye sahiptir.

$\mathbf{H}_{4}$ : Çevrimiçi seyahat rezervasyonuna yönelik algılanan zaman riski kullanma eğilimi üzerinde anlamlı ve olumsuz etkiye sahiptir.

H5: Çevrimiçi seyahat rezervasyonuna yönelik algılanan sosyal risk kullanma eğilimi üzerinde anlamlı ve olumsuz etkiye sahiptir. 


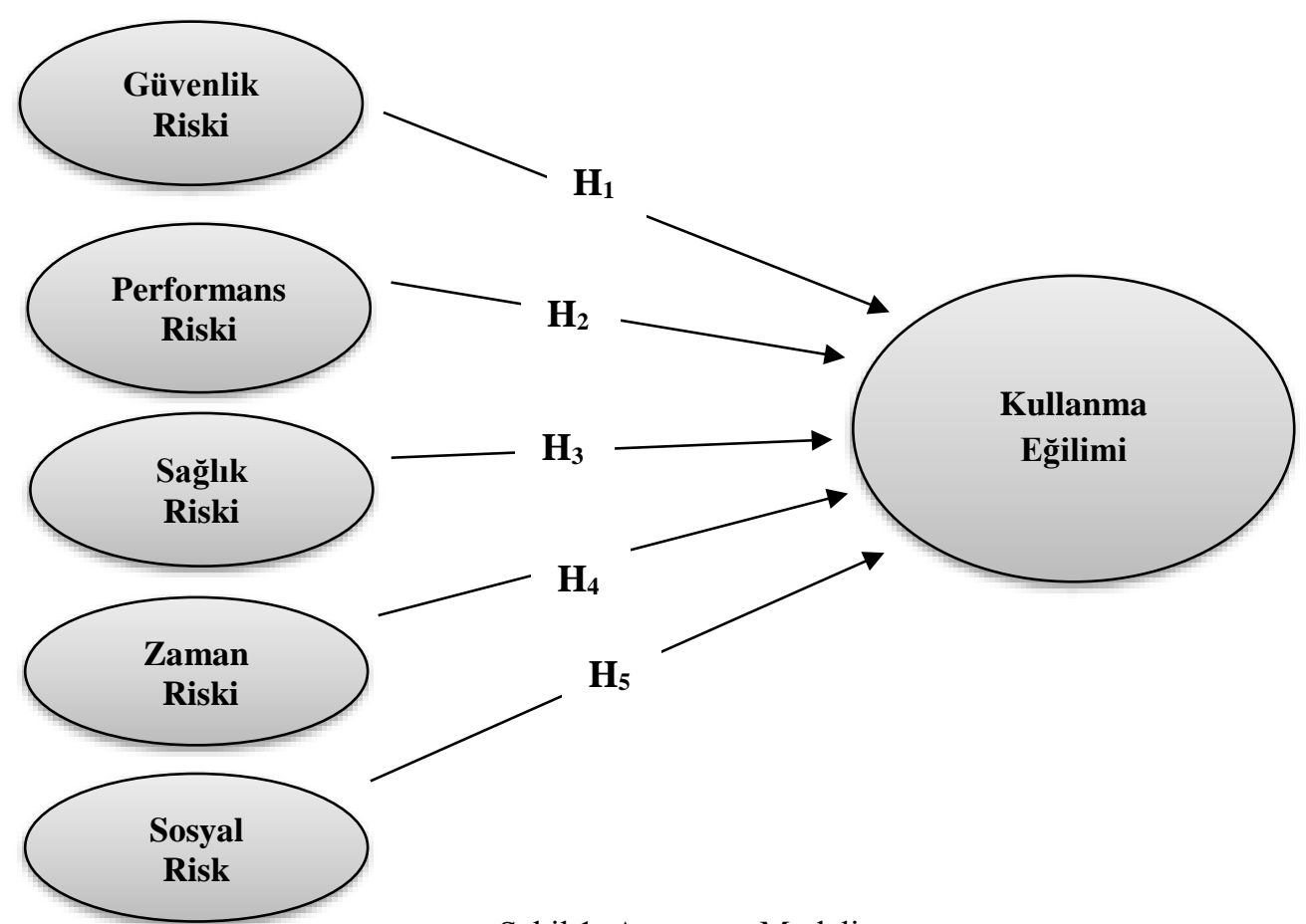

Şekil 1. Araştırma Modeli

Araştırmanın evrenini, Zonguldak Bülent Ecevit Üniversitesi merkez ve çevre kampüslerinde çalışan akademik ve idari personel oluşturmaktadır. Araştırma evreni olarak akademik ve idari personelin seçilmesinde, aylık düzenli gelire sahip olmaları, eğitim, seminer, kongre, konferans, hizmet içi eğitim gibi nedenlerle sürekli seyahat etmeleri, konaklama ve ulaşım tarihlerinin genellikle önceden belli olması nedeniyle rezervasyonlu seyahat etmeyi tercih etmeleri etkili olmuştur. Zonguldak Bülent Ecevit Üniversitesi resmi internet sitesinde (https://w3.beun.edu.tr/) yer alan bilgilere göre, 2018 yılı itibariyle 1217 akademik, 2192 idari olmak üzere toplam personel sayısı 3409 kişidir. Evrenin tamamına ulaşmanın zaman, maliyet ve ulaşılabilirlik gibi nedenlerle güç olması nedeniyle evreni temsil yeteneğine sahip örneklem alma yoluna gidilmiştir. Basit tesadüfi örnekleme yöntemiyle seçilen 355 akademik ve idari personelden veriler elde edilmiştir. Ural ve Kılıç $(2013,47), 3500$ kişiye kadar olan evren (N) büyüklüklerinde minimum örneklem (n) büyüklüğünü 346 kişi olarak belirtmektedirler (hata pay1=\%5). Bu örneklem sayısı Balc1 (2009, 101-102) ve Y1ldız (2017, 442) tarafından da yeterli görümektedir. Dolayısıyla, bu araştırmadaki örneklem boyutunun ( $\mathrm{n}=355)$ yeterli büyüklükte olduğunu belirtmek mümkündür.

Nicel veri toplama tekniklerinden biri olan anket tekniği kullanılarak araştırma verileri elde edilmiştir. Ankette kullanılan ölçeğin geliştirilmesinde Zhang vd. (2012), Kim, Kim ve Leong (2005) ve Kim, Qu ve Kim (2009) çalışmalarında kullanılan ölçeklerden ve uzman görüşlerinden yararlanılarak ifadeler bu araştırmaya uygun hale getirilmiştir. İki bölümden oluşan bu anketin ilk bölümünde, çevrimiçi seyahat rezervasyonuna yönelik tüketicilerin algıladıkları risk faktörleri ve kullanma eğilimine etkisini ölçmeye yönelik 5'li Likert (1="Kesinlikle Katılmıyorum", 2="Kat1lmiyorum", 3="Kismen Kat1liyorum Kismen Katılmıyorum", 4="Kat1liyorum", 5="Kesinlikle Katılıyorum") ölçeğinde hazırlanan ifadeler yer almaktadır. İkinci bölümde ise ankete katılanların sosyo-demografik özellikleri ile çevrimiçi rezervasyonu daha önce kullanıp kullanmama durumu, çevrimiçi rezervasyon ve günlük internet kullanım sıklığı, çevrimiçi rezervasyon yapma kararı almada bilgi alınan kaynaklar, hangi turistik hizmetlerin rezervasyonunun çevrimiçi ortamda yapıldığını tespit etmeye yönelik ifadeler yer almaktadır.

Araştırmada öncelikle, katılımcıların sosyo-demografik özellikleri ile çevrimiçi seyahat rezervasyonunu kullanımlarına yönelik tanımlayıcı sorulara verdikleri cevaplara ilişkin elde edilen bulgular yüzde ve frekans dağılımlarına göre analiz edilmiştir. Daha sonraki kısımda ise çevrimiçi seyahat rezervasyonuna yönelik algılanan risk boyutlarına dair faktör analizi gerçekleştirilmiştir. Bununla birlikte, ankete katılanların sosyo-demografik özellikleri ve çevrimiçi seyahat rezervasyonunu kullanımlarıyla algılanan risk faktörleri arasında anlamlı bir farklılık olup olmadığı ttesti ve Anova testi ile analiz edilmiştir. Ayrıca, çevrimiçi seyahat rezervasyonuna yönelik algılanan risk faktörleri ile kullanma eğilimi arasındaki ilişki basit korelasyon analizi yardımı ile test edilmiştir. Katılımcıların çevrimiçi seyahat rezervasyonunu kullanma eğilimi üzerinde etkili olan algılanan risk faktörlerinin hangileri olduğunun tespitinde çoklu doğrusal regresyon analizi kullanılmıştır.

Gerçekleştirilecek analizlerde hangi istatistiksel yöntemlerin kullanılacağına karar verilmesi için normal dağılım testi gerçekleştirilmiştir. George ve Mallery’e $(2014,71)$ göre, normal dağılım testleri sonucu elde edilen çarpıklık ve basıklık değerlerinin -2 ve +2 aralığında olması normal dağılım olduğunu göstermektedir. Hair Jr. vd. (2014: 32) ise bu değerlerin -1 ile +1 arasında olması gerektiğini belirtmektedirler. Bu noktadan hareketle, Tablo 2'deki çarpıklık-basıklık değerleri dikkate alındığında, bu araştırma sonucu elde edilen verilerin normal dağılım gösterdiği görülmektedir. Bu sebeple, bu araştırma amacı doğrultusunda kullanılacak istatistiksel analizlerde parametrik testler kullanılacaktır. 
Tablo 2. Normal Dağılım Testi

\begin{tabular}{|c|c|c|c|}
\hline & & İstatistik Değeri & $\begin{array}{c}\text { Standart Hata } \\
\text { Değeri }\end{array}$ \\
\hline $\begin{array}{l}\text { Çevrimiçi Seyahat } \\
\text { Rezervasyonuna }\end{array}$ & Çarpıklık & ,203 & , 129 \\
\hline $\begin{array}{l}\text { Risk ve Kullanma } \\
\text { Eğilimi Ölçeği }\end{array}$ & Basıklık & ,535 & ,258 \\
\hline
\end{tabular}

Araştırmada kullanılan ölçeğin güvenilirliğini ölçmeye yönelik güvenilirlik analizi gerçekleştirilmiş, elde edilen Cronbach Alpha değeri 0,903 olmuştur. Güvenirlik katsayısı, 0 ile 1 arasında değerler alır, bu değer 1'e yaklaştıkça güvenirlik artmaktadır (Ural ve Kılıç 2013, 80; Kayış 2010, 405). Dolayısıyla bu araştırmada kullanılan ölçeğin güvenirliğinin oldukça yüksek olduğunu belirtmek mümkündür. Bu araştırmada elde edilen verilerin analizinde SPSS 21.0 for Windows programı kullanılmıştır. Analiz edilen veriler tablolara aktarılmış ve araştırmacılar tarafından yorumlanmıştır.

\section{Bulgular}

\subsection{Sosyo-Demografik Özelliklere İlişkin Bulgular}

Araştırmaya katılanların sosyo-demografik özelliklerine ilişkin bulgular Tablo 3 ’te yer almaktadır.

Tablo 3. Katılımcıların Sosyo-Demografik Özellikleri

\begin{tabular}{|c|c|c|c|c|c|c|c|}
\hline Değişkenler & Gruplar & f & $\%$ & Değişkenler & Gruplar & f & $\%$ \\
\hline \multirow{3}{*}{ Cinsiyet } & Erkek & 198 & 55,8 & \multirow{4}{*}{$\begin{array}{l}\text { Eŭgitim } \\
\text { Düzeyi }\end{array}$} & Lise & 19 & 5,4 \\
\hline & Kadın & 157 & 44,2 & & Önlisnas & 23 & 6,5 \\
\hline & $21-30$ & 65 & 18,3 & & Lisans & 86 & 24,2 \\
\hline \multirow{4}{*}{ Yaş } & $31-40$ & 190 & 53,5 & & Lisansüstü & 227 & 63,9 \\
\hline & $41-50$ & 79 & 22,3 & \multirow{2}{*}{ Meslek } & Akademisyen & 223 & 62,8 \\
\hline & $51-60$ & 16 & 4,5 & & Memur & 132 & 37,2 \\
\hline & $\begin{array}{l}61 \text { ve } \\
\text { üzeri }\end{array}$ & 5 & 1,4 & \multirow{4}{*}{$\begin{array}{l}\text { Hane Halkı } \\
\text { Gelir } \\
\text { Durumu } \\
\text { (TL) }\end{array}$} & $2500-5000$ & 139 & 39,2 \\
\hline \multirow{3}{*}{ Medeni Hal } & Evli & 237 & 66,8 & & $5001-7500$ & 89 & 25,1 \\
\hline & Bekar & 118 & 33,2 & & $7501-10000$ & 98 & 27,6 \\
\hline & & & & & 10000 ve üzeri & 29 & 8,2 \\
\hline
\end{tabular}

Tablo 3'teki veriler incelendiğinde, ankete katılan erkek sayısının ( $\mathrm{n}=198)$ kadın sayısına $(\mathrm{n}=157)$ oranla biraz daha fazla olduğu ve katılımcıların yarısından fazlasının (\%53,5) 31-40 yaş aralığında oldukları görülmektedir. Diğer sosyodemografik verilere bakıldığında, katılımcıların çoğunlukla evli $(\% 66,8)$ ve akademisyen $(\% 62,8)$ olduğu, eğitim durumlarının ise büyük oranda lisansüstü $(\% 63,9)$ düzeyde olduğu ortaya çıkmaktadır. Katılımcıların hane halkı gelir durumları ise aylık 2500-5000 TL (\%39,2), 7501-10000 TL (\%27,6) ve 5001-7500 TL (\%25,1) oranlarında çoğunluk arz etmektedir. 
Ercan, F., Köşker, H., Albuz, N. / Journal of Yasar University, 2020, 15/59, 624-641

\section{2. Çevrimiçi Seyahat Rezervasyonu Kullanımına Yönelik Bulgular}

Tablo 4'de, katılımcıların çevrimiçi seyahat rezervasyonu kullanımlarına yönelik tanımlayıcı sorulara ilişkin bulgular yer almaktadır.

Tablo 4. Katılımcıların Çevrimiçi Seyahat Rezervasyonu Kullanımlarına İlişkin Bulgular

\begin{tabular}{|c|c|c|c|}
\hline Değişkenler & Gruplar & $\mathbf{f}$ & $\%$ \\
\hline \multirow{5}{*}{$\begin{array}{l}\text { Günlük Ortalama } \\
\text { İnternet Kullanım } \\
\text { Sıklığı }\end{array}$} & 1 saatten daha az & 15 & 4,2 \\
\hline & 1-3 saat & 125 & 35,2 \\
\hline & 4-6 saat & 135 & 38,0 \\
\hline & $7-9$ saat & 58 & 16,3 \\
\hline & 10 saat ve daha fazla & 22 & 6,2 \\
\hline \multirow{2}{*}{$\begin{array}{l}\text { İnternet Ortamında } \\
\text { Rezervasyon Yapıp } \\
\text { Yapmama Durumu }\end{array}$} & Evet & 326 & 91,8 \\
\hline & Hayır & 29 & 8,2 \\
\hline \multirow{6}{*}{$\begin{array}{l}\text { Rezervasyonu } \\
\text { Yapılan Turistik } \\
\text { Ürün }\end{array}$} & Otobüs Bileti & 300 & 84,5 \\
\hline & Araba Kiralama & 49 & 13,8 \\
\hline & Uçak Bileti & 254 & 71,5 \\
\hline & Restoran/Lokanta & 66 & 18,6 \\
\hline & Otel & 253 & 71,3 \\
\hline & Gezi/Tur & 129 & 36,3 \\
\hline \multirow{4}{*}{$\begin{array}{l}\text { İnternet Üzerinden } \\
\text { Rezervasyon Yapma } \\
\text { Sıklığı }\end{array}$} & Yilda 1 Defa & 41 & 11,5 \\
\hline & Y1lda 2-3 Defa & 115 & 32,4 \\
\hline & Yilda 4-5 Defa & 79 & 22,3 \\
\hline & $\begin{array}{l}\text { Yilda } 6 \text { Defa ve Daha } \\
\text { Fazla }\end{array}$ & 91 & 25,6 \\
\hline \multirow{9}{*}{$\begin{array}{l}\text { Rezervasyon Bilgi } \\
\text { Kaynakları }\end{array}$} & Televizyon & 47 & 13,2 \\
\hline & Sosyal Medya & 125 & 35,2 \\
\hline & Reklam & 47 & 13,2 \\
\hline & Arkadaşlar & 168 & 47,3 \\
\hline & İnternet & 166 & 46,8 \\
\hline & Arama Motoru & 32 & 9,0 \\
\hline & Otel İnternet Siteleri & 35 & 9,9 \\
\hline & $\begin{array}{l}\text { Acenta İnternet } \\
\text { Siteleri }\end{array}$ & 38 & 10,7 \\
\hline & $\begin{array}{l}\text { Havayolu İşletmeleri } \\
\text { İnternet Siteleri }\end{array}$ & 26 & 7,3 \\
\hline
\end{tabular}

Çevrimiçi seyahat rezervasyonu kullanımına yönelik katılımcılara yöneltilen sorulara verilen cevaplar incelendiğinde, günlük ortalama internet kullanım sıklığının katılımcılar arasında 4-6 saat (\%38) ve 1-3 saat (\%35,2) olarak yoğunlaştığı ve katılımcıların tamamına yakınının $(\% 91,8)$ daha önce çevrimiçi seyahat rezervasyonu yaptırmış olduğu görülmektedir. Yılda 2-3 defa seyahat rezervasyonu yaptıranların çoğunlukta olduğu $(\% 32,4)$, çevrimiçi seyahat rezervasyonunun en çok kullanıldığı başlıca turistik ürünlerin ise sırasıyla otobüs bileti $(\% 84,5)$, uçak bileti $(\% 71,5)$ ve otel rezervasyonu $(\% 71,3)$ olduğu araştırmada elde edilen veriler arasında yer almaktadır. Bununla birlikte, katılımcıların çevrimiçi seyahat rezervasyonu yapma kararı alırken en çok başvurdukları bilgi kaynakları da arkadaşlar (\% 47,3$)$, internet $(\% 46,8)$ ve sosyal medya $(\% 35,2)$ olarak dikkat çekmektedir. 


\section{3. Çevrimiçi Seyahat Rezervasyonuna Yönelik Algılanan Risk Boyutlarına İlişkin Faktör Analizi}

Tablo 5'te, katılımcıların çevrimiçi seyahat rezervasyonuna yönelik algılanan risk boyutlarına ilişkin faktör analizi ve güvenirlik analizi değerleri görülmektedir. Ayrıca, algılanan risk boyutlarına ilişkin katılımcıların görüşlerinin aritmetik ortalaması, faktör yükleri ve özdeğerleri ile açıklanan varyans oranları yer almaktadır.

Tablo 5. Katılımcıların Çevrimiçi Seyahat Rezervasyonuna Yönelik Algılanan Risk Boyutlarına İlişkin Açımlayıcı Faktör Analizi (AFA)

\begin{tabular}{|c|c|c|c|c|c|}
\hline Faktörler & $\begin{array}{l}\text { Faktör } \\
\text { Yükleri }\end{array}$ & Özdeğerler & $\begin{array}{c}\text { Faktör } \\
\text { Açıklayıcılığı }\end{array}$ & $\begin{array}{l}\text { Güvenilirlik } \\
\text { (a) }\end{array}$ & $\begin{array}{c}\text { Aritmetik } \\
\text { Ortalama } \\
(1-5)^{*}\end{array}$ \\
\hline Güvenlik Riski & & 11,051 & 17,754 & 0,940 & $\mathbf{3 , 3 2}$ \\
\hline $\begin{array}{lrr}\text { İnternet üzerinden } & \text { seyahat } \\
\text { rezervasyonunda özel } & \text { bilgilerimi } \\
\text { gönderirken kendimi güvende hissetmem. }\end{array}$ & 0,743 & & & & 3,21 \\
\hline $\begin{array}{l}\text { İnternet üzerinden seyahat rezervasyonu } \\
\text { yaparken kredi kartı bilgilerinin çalınma } \\
\text { olasılığ yüksektir. }\end{array}$ & 0,846 & & & & 3,25 \\
\hline $\begin{array}{l}\text { Kişisel bilgilerin gönderilmesinde internet } \\
\text { ağı genelde tehlikeli bir ortamdır. }\end{array}$ & 0,881 & & & & 3,46 \\
\hline $\begin{array}{l}\text { İnternet rezervasyonu, özel bilgileri } \\
\text { vermek için güvenilir değildir. }\end{array}$ & 0,858 & & & & 3,34 \\
\hline $\begin{array}{l}\text { İnternet üzerinden seyahat rezervasyonu } \\
\text { yaparken verdiğim kişisel bilgilerin } \\
\text { çalınma ihtimali yüksektir. }\end{array}$ & 0,901 & & & & 3,34 \\
\hline Performans Riski & & 4,377 & 15,996 & 0,893 & 2,91 \\
\hline $\begin{array}{l}\text { İnternet üzerinden seyahat rezervasyonu } \\
\text { yaparken } \quad \text { beklenen } \\
\text { alabileceğimden emin değilim. }\end{array}$ & 0,805 & & & & 2,84 \\
\hline $\begin{array}{l}\text { İnternet üzerinden satın alacağım seyahat } \\
\text { hizmetinin vaad edilen } \\
\text { gösterip gerformansı } \\
\text { endişe duyarım. }\end{array}$ & 0,816 & & & & 3,07 \\
\hline 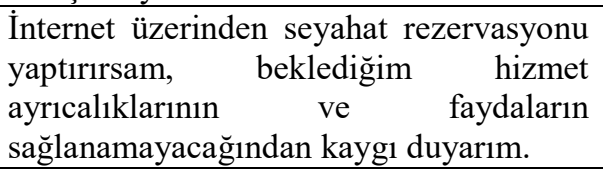 & 0,851 & & & & 2,96 \\
\hline $\begin{array}{lrr}\text { İnternet üzerinden } & \text { gerçekleştirilen } \\
\text { rezervasyon hizmetlerinin performansiyla } \\
\text { ilgili meydana gelebilecek } & \text { sorunları } \\
\text { düşündügüumde çevrimiçi } & \text { seyahat } \\
\text { rezervasyonunu çok riskli buluyorum. }\end{array}$ & 0,722 & & & & 2,79 \\
\hline Sağlık Riski & & 1,678 & 15,587 & 0,891 & 1,92 \\
\hline $\begin{array}{l}\text { Seyahat rezervasyonu için interneti } \\
\text { kullanmanın uyku bozukluğu, bel ve sırt } \\
\text { ağrıları gibi rahatsılık verici fiziksel yan } \\
\text { etkilere neden olabileceğinden endişe } \\
\text { duyarım. }\end{array}$ & 0,771 & & & & 1,81 \\
\hline $\begin{array}{l}\text { İnternet üzerinden seyahat rezervasyonu } \\
\text { yaptırma ile ilişkili muhtemel sağlık } \\
\text { risklerinden endişe duyarım. }\end{array}$ & 0,785 & & & & 1,69 \\
\hline $\begin{array}{l}\text { İnternet üzerinden seyahat rezervasyonu } \\
\text { yaparken bilgisayar, tablet ya da akıllı } \\
\text { telefon ekranına bakmaktan kaynaklı } \\
\text { muhtemel göz yorgunluğu ve } \\
\text { rahatsizlıklarından kaygı duyarım. }\end{array}$ & 0,760 & & & & 1,89 \\
\hline $\begin{array}{l}\text { İnternet üzerinden seyahat rezervasyonu } \\
\text { yapma düşüncesi istemsiz bir kaygı } \\
\text { duymama neden olur. }\end{array}$ & 0,594 & & & & 2,15 \\
\hline
\end{tabular}




\begin{tabular}{|c|c|c|c|c|c|}
\hline $\begin{array}{l}\text { İnternet üzerinden seyahat rezervasyonu } \\
\text { yapma düsüncesi bana psikolojik bir } \\
\text { rahatsizlı hissi verir. }\end{array}$ & 0,644 & & & & 1,92 \\
\hline $\begin{array}{l}\text { İnternet üzerinden seyahat rezervasyonu } \\
\text { yapma fikri gereksiz bir gerginlik hissi } \\
\text { yaşamama neden olur. }\end{array}$ & 0,574 & & & & 2,07 \\
\hline Zaman Riski & & 1,211 & 12,673 & 0,911 & 1,87 \\
\hline $\begin{array}{l}\text { İnternet üzerinden seyahat rezervasyonu } \\
\text { yaptırma çok fazla vaktimi alacak bir } \\
\text { işlemdir. }\end{array}$ & 0,809 & & & & 1,97 \\
\hline $\begin{array}{l}\text { İnternet üzerinden seyahat rezervasyonu } \\
\text { yaptırma zamanımın boşa gitmesine } \\
\text { neden olacaktır. }\end{array}$ & 0,817 & & & & 1,79 \\
\hline $\begin{array}{l}\text { İnternet üzerinden seyahat rezervasyonu } \\
\text { yaptırma zamanımı verimsiz kullanmama } \\
\text { neden olur. }\end{array}$ & 0,783 & & & & 1,83 \\
\hline $\begin{array}{l}\text { Günlük programımda internet üzerinden } \\
\text { seyahat rezervasyonu yaptırmak için vakit } \\
\text { ayırmak üzerimde gereksiz bir zaman } \\
\text { baskısı oluşturur. }\end{array}$ & 0,711 & & & & 1,90 \\
\hline Sosyal Risk & & 1,065 & 9,779 & 0,835 & 1,75 \\
\hline $\begin{array}{l}\text { İnternet üzerinden seyahat rezervasyonu } \\
\text { yaptırmam, fikirlerine değer verdiğim } \\
\text { kişilerin bunu saçma ve akılsız olarak } \\
\text { değerlendirmesine neden olabilir. }\end{array}$ & 0,663 & & & & 1,96 \\
\hline $\begin{array}{l}\text { İnternet üzerinden seyahat rezervasyonu } \\
\text { yapmak diğer kişilerin benim hakkımdaki } \\
\text { fikirlerini olumsuz yönde etkiler. }\end{array}$ & 0,676 & & & & 1,67 \\
\hline $\begin{array}{l}\text { İnternet üzerinden seyahat rezervasyonu } \\
\text { yaptırmanın, arkadaşlarım tarafindan } \\
\text { gösteriş yaptığım düşüncesine neden } \\
\text { olacağından kaygı duyarım. }\end{array}$ & 0,614 & & & & 1,62 \\
\hline \multicolumn{6}{|c|}{$\begin{array}{l}\text { Kaiser-Meyer-OIkin Örneklem Yeterliliği }=.917 \text {, Bartlett's Test of Sphericity: } \mathrm{p}<.0,00 \text { (Chi-Square } 7988,493 \\
\text { df=351), Açılanan Kümülatif Varyans: } \% 71,788 .\end{array}$} \\
\hline
\end{tabular}

Çevrimiçi seyahat rezervasyonuna yönelik algılanan risk faktörlerine ilişsin ölçekte 22 ifade bulunmaktadır. Araştırma verilerinin faktör analizine uygunluğunun tespiti için Barlett testi ve Kaiser-Meyer Olkin (KMO) örneklem büyüklüğü testleri yapılmıştır. Barlett testi, elde edilen $p$ değerinin anlamlı olduğunu $(\mathrm{p}<0.00), \mathrm{KMO}$ değeri $(0,917)$ verilerin faktör analizi yapmak için uygun olduğunu göstermektedir (Kalaycı 2010, 322). Faktör analizi sonuçları, çevrimiçi seyahat rezervasyonuna yönelik algılanan risklere ilişkin ölçekteki ifadelerin beş boyutta toplandığını göstermektedir. Bu boyutların özdeğerleri 1'den büyük ve toplam varyansın \% 71,788 'ini açıklamaktadır. Ölçekte bulunan güvenlik riski $(0,940)$, performans riski $(0,893)$, sağlık riski $(0,891)$, zaman riski $(0,911)$ ve sosyal risk $(0,835)$ algılanan risk alt boyutlarının güvenirlik katsayıları hesaplanmış ve güvenirliğin yüksek dercede (Kayış 2010, 405) olduğu tespit edilmiştir.

Tablo 5 'te, faktörlere ait aritmetik ortalamalara bakıldığında, güvenlik riski faktörüne ait genel aritmetik ortalamanın $\overline{\mathrm{X}}=3,32$ olduğu görülmektedir. Buradan hareketle, katılımcıların çevrimiçi seyahat rezervasyonuna yönelik algılanan güvenlik risklerinin ortalamanın üzerinde bir düzeyde olduğunu belirtmek mümkündür. Algılanan performans riski faktörüne ait aritmetik ortalamaya bakıldığında, ortalamaya yakın düzeyde olduğu $(\bar{X}=2,91)$, algılanan sağlık riski $(\bar{X}$ $=1,92)$, zaman riski $(\bar{X}=1,87)$ ve sosyal riske $(\bar{X}=1,75)$ ilişkin aritmetik ortalamaların ise ortalamanın altında düzeyde olduğu görülmektedir. Elde edilen bu verilere göre, katılımcıların çevrimiçi seyahat rezervasyonuna yönelik algıladıkları riskler güvenlik riski boyutunda ortalamanın üzerinde en fazla iken, algılanan performans riski bunu takip etmektedir. Algılanan güvenlik riski boyutunda "Kişisel bilgilerin gönderilmesinde internet ağı genelde tehlikeli bir ortamdır." İfadesi katılımcılar tarafindan en yüksek düzeyde $(\bar{X}=3,46)$ onay gören ifadedir. Algılanan performans riski boyutunda ise "İnternet üzerinden satın alacağım seyahat hizmetinin vaad edilen performansı gösterip göstermeyeceği konusunda endişe duyarım." ifadesi katılımcılar tarafından en yüksek düzeyde onaylanan ifade olarak görülmektedir.

\subsection{Kullanma Ĕ̆ilimi Ölçeği}

Tablo 6'da, katılımcıların çevrimiçi seyahat rezervasyonunu kullanma eğilimlerine ilişkin ölçeğe ait güvenilirlik analizi, aritmetik ortalama ve standart sapma değerleri yer almaktadır. Ölçeğe ait Croncbach Alpha değeri 0,938, aritmetik 
ortalama ise $\overline{\mathrm{X}}=3.70$ 'dir. Bu sonuç, katılımcıların çevrimiçi seyahat rezervasyonunu kullanma eğilimlerinin ortalamanın üzerinde olduğunu göstermektedir.

Tablo 6. Kullanma Eğilimi Ölçeği

\begin{tabular}{|l|c|c|c|}
\hline \multicolumn{1}{|c|}{ Faktör } & $\begin{array}{c}\text { Aritmetik } \\
\text { Ortalama }(\overline{\mathrm{X}})\end{array}$ & $\begin{array}{c}\text { Standart } \\
\text { Sapma }\end{array}$ & $\begin{array}{c}\text { Güvenilirlik } \\
(\mathbf{a})\end{array}$ \\
\hline Kullanma Eğilimi & $\mathbf{3 , 7 0}$ & $\mathbf{1 , 0 3}$ & $\mathbf{0 , 9 3 8}$ \\
\hline $\begin{array}{l}\text { Seyahat rezervasyonu yaptırmada interneti kullanmak iyi bir } \\
\text { fikirdir. }\end{array}$ & & 0,98 & \\
\hline $\begin{array}{l}\text { Seyahat rezervasyonu yaptırmak için interneti kullanmak } \\
\text { benim için uygun bir yöntemdir. }\end{array}$ & & 1,04 & \\
\hline $\begin{array}{l}\text { Seyahatlerimde internet üzerinden rezervasyonu skklıkla } \\
\text { kullanmaya özen göstereceğim. }\end{array}$ & & 1,07 & \\
\hline $\begin{array}{l}\text { İnernet üzerinden seyahat rezervasyonunu gelecekte de } \\
\text { kullanacağım. }\end{array}$ & & 0,99 & \\
\hline $\begin{array}{l}\text { Seyahat rezervasyonlarımı internet üzerinden yapmak } \\
\text { öncelikli tercihim olacaktır. }\end{array}$ & & 1,08 & \\
\hline
\end{tabular}

\section{5. Çevrimiçi Seyahat Rezervasyonuna Yönelik Algılanan Risk Faktörlerinin Cinsiyet, Medeni Hal ve Mesleğe Göre Karşılaştırılması (Bağımsız Gruplar İçin T Testi)}

Tablo 7'de, çevrimiçi seyahat rezervasyonuna yönelik algılanan risklerin katılımcıların cinsiyeti, medeni hal ve mesleklerine göre istatiksel olarak anlamlı bir farklılık gösterip göstermediğine ilişkin bağımsız gruplar için $\mathrm{t}$ testi analiz sonuçları görülmektedir. Anlamlı bulunmayan boyutlara tabloda yer verilmemiştir.

Tablo 7. Çevrimiçi Seyahat Rezervasyonuna Yönelik Algılanan Risklerin Cinsiyet, Medeni Hal ve Mesleğe Göre Karşılaştırılması

\begin{tabular}{|c|c|c|c|c|c|c|c|}
\hline Faktör & Değişkenler & $\begin{array}{l}\text { Sayı } \\
(\mathbf{N})\end{array}$ & $\begin{array}{c}\text { Aritmetik } \\
\text { Ortalama }(\bar{X})\end{array}$ & $\begin{array}{c}\text { Standart } \\
\text { Sapma } \\
\text { (S.S.) }\end{array}$ & $\begin{array}{c}\mathrm{t}- \\
\text { Değeri }\end{array}$ & $\begin{array}{l}\text { Serbestlik } \\
\text { Derecesi } \\
\text { (df) }\end{array}$ & $\begin{array}{c}\text { p- } \\
\text { Değeri }\end{array}$ \\
\hline \multirow{2}{*}{ Sosyal Risk } & Erkek & 198 & 1,93 & 0,86 & \multirow{2}{*}{4,74} & \multirow{2}{*}{353} & \multirow{2}{*}{0,000} \\
\hline & Kadın & 157 & 1,52 & 0,72 & & & \\
\hline \multirow{2}{*}{ Sosyal Risk } & Evli & 237 & 1,84 & 0,89 & \multirow{2}{*}{2,91} & \multirow{2}{*}{353} & \multirow[t]{2}{*}{0,004} \\
\hline & Bekar & 118 & 1,57 & 0,64 & & & \\
\hline \multirow{2}{*}{$\begin{array}{l}\text { Güvenlik } \\
\text { Riski }\end{array}$} & Akademisyen & 223 & 3,19 & 1,09 & \multirow{2}{*}{3,01} & \multirow{2}{*}{353} & \multirow[t]{2}{*}{0,003} \\
\hline & Memur & 132 & 3,53 & 0,87 & & & \\
\hline \multirow{2}{*}{$\begin{array}{l}\text { Performans } \\
\text { Riski }\end{array}$} & Akademisyen & 223 & 2,77 & 1,03 & \multirow{2}{*}{3,55} & \multirow{2}{*}{353} & \multirow{2}{*}{0,000} \\
\hline & Memur & 132 & 3,15 & 0,84 & & & \\
\hline \multirow{2}{*}{ Sağlık Riski } & Akademisyen & 223 & 1,79 & 0,78 & \multirow{2}{*}{3,96} & \multirow{2}{*}{353} & \multirow{2}{*}{0,000} \\
\hline & Memur & 132 & 2,14 & 0,83 & & & \\
\hline \multirow{2}{*}{ Zaman Riski } & Akademisyen & 223 & 1,77 & 0,86 & \multirow{2}{*}{2,81} & \multirow{2}{*}{353} & \multirow{2}{*}{0,005} \\
\hline & Memur & 132 & 2,05 & 0,92 & & & \\
\hline \multirow{2}{*}{ Sosyal Risk } & Akademisyen & 223 & 1,59 & 0,74 & \multirow{2}{*}{4,81} & \multirow{2}{*}{353} & \multirow[t]{2}{*}{0,000} \\
\hline & Memur & 132 & 2,02 & 0,89 & & & \\
\hline
\end{tabular}

Analizler sonucu elde edilen veriler incelendiğinde (Tablo 7), erkek ve kadın katılımcılarla evli ve bekar katılımcıların algılanan sosyal risklerinin, 0,05 anlamlılık düzeyinde istatistiksel açıdan anlamlı farklılık gösterdiği ortaya çıkmaktadır. Test sonuçlarına göre, erkek $(\bar{X}=1,93)$ ve evli $(\bar{X}=1,84)$ katılımcıların çevrimiçi seyahat rezervasyonuna yönelik algılanan sosyal risk düzeylerinin kadın $(\overline{\mathrm{X}}=1,52)$ ve bekar $(\overline{\mathrm{X}}=1,57)$ katılımcılara göre daha yüksek olduğu görülmektedir. Bununla birlikte, mesleklere göre algılanan risk boyutlarının tamamının anlamlı farklılıklar gösterdiği dikkat çekmektedir $(\mathrm{p}<0,05)$. Buna göre, memur katılımcıların algılanan güvenlik $(\overline{\mathrm{X}}=3,53)$, performans $(\overline{\mathrm{X}}=3,15)$, sağlık $(\bar{X}=2,14)$, zaman $(\bar{X}=2,05)$ ve sosyal $(\bar{X}=2,02)$ risk düzeylerinin akademisyen katılımcılara göre daha yüksek olduğunu belirtmek mümkündür.

4.6. Çevrimiçi Seyahat Rezervasyonuna Yönelik Algılanan Risk Faktörlerinin Yaş, Eğitim Düzeyi, Hane Halkı Gelir Durumu, Günlük Ortalama Internet Kullanım Siklı̆̆ı, İnternet Üzerinden Rezervasyon Yapma Sıklığına Göre Karşılaştırılması (Anova Testi) 
Tablo 8'de, katılımcıların çevrimiçi seyahat rezervasyonuna yönelik algıladıkları risklerin yaş, eğitim düzeyi ve hane halkı gelir durumuna göre karşılaştırılmasını içeren bağımsız örneklemler için tek yönlü varyans analizi (Anova) testi sonuçları görülmektedir. Anlamlı bulunmayan boyutlara tabloda yer verilmemiştir.

Tablo 8. Çevrimiçi Seyahat Rezervasyonuna Yönelik Algılanan Risklerin Yaş, Eğitim Düzeyi ve Hane Halkı Gelir Durumuna Göre Karşılaştırılması

\begin{tabular}{|c|c|c|c|c|c|c|}
\hline Faktör & Değişkenler & $\begin{array}{l}\text { Sayı } \\
(\mathbf{N})\end{array}$ & $\begin{array}{c}\text { Aritmetik Ortalama } \\
(\bar{X})\end{array}$ & $\begin{array}{c}\text { Standart Sapma } \\
\text { (S.S.) }\end{array}$ & $\begin{array}{c}\text { F- } \\
\text { Değeri }\end{array}$ & $\begin{array}{c}\text { p- } \\
\text { Değeri }\end{array}$ \\
\hline \multirow{4}{*}{$\begin{array}{l}\text { Performans } \\
\text { Riski }\end{array}$} & Lise & 19 & 2,93 & 0,66 & \multirow{4}{*}{4,140} & \multirow{4}{*}{0,007} \\
\hline & Önlisans (a) & 23 & 3,48 & 0,83 & & \\
\hline & Lisans & 86 & 3,04 & 0,88 & & \\
\hline & Lisansüstü(a) & 227 & 2,80 & 1,03 & & \\
\hline \multirow{4}{*}{ Sağlık Riski } & Lise (a) & 19 & 2,47 & 1,05 & \multirow{4}{*}{5,498} & \multirow{4}{*}{0,001} \\
\hline & Önlisans & 23 & 2,09 & 0,73 & & \\
\hline & Lisans & 86 & 2,05 & 0,77 & & \\
\hline & Lisansüstü (a) & 227 & 1,81 & 0,80 & & \\
\hline \multirow{4}{*}{ Zaman Riski } & Lise (a) & 19 & 2,56 & 1,24 & \multirow{4}{*}{4,750} & \multirow{4}{*}{0,003} \\
\hline & Önlisans (a) & 23 & 1,66 & 0,52 & & \\
\hline & Lisans (a) & 86 & 1,93 & 0,89 & & \\
\hline & Lisansüstü (a) & 227 & 1,82 & 0,86 & & \\
\hline \multirow{4}{*}{ Sosyal Risk } & Lise (a) & 19 & 2,26 & 0,87 & \multirow{4}{*}{7,144} & \multirow{4}{*}{0,000} \\
\hline & Önlisans & 23 & 1,98 & 0,71 & & \\
\hline & Lisans (b) & 86 & 1,95 & 0,95 & & \\
\hline & $\begin{array}{l}\text { Lisansüstü (a) } \\
\text { (b) }\end{array}$ & 227 & 1,61 & 0,74 & & \\
\hline \multirow{4}{*}{ Sağlık Riski } & $\begin{array}{l}2500-5000 \\
\text { (a)(b) }\end{array}$ & 139 & 2,10 & 0,83 & \multirow{4}{*}{3,821} & \multirow{4}{*}{0,010} \\
\hline & $5001-7500$ (a) & 89 & 1,809 & 0,73 & & \\
\hline & 7501-10000(b) & 98 & 1,802 & 0,77 & & \\
\hline & 10001 ve üzeri & 29 & 1,83 & 0,99 & & \\
\hline \multirow{4}{*}{ Zaman Riski } & $\begin{array}{l}2500-5000 \\
(\mathrm{a})(\mathrm{b})\end{array}$ & 139 & 2,10 & 0,96 & \multirow{4}{*}{5,252} & \multirow{4}{*}{0,001} \\
\hline & $5001-7500$ (a) & 89 & 1,72 & 0,71 & & \\
\hline & 7501-10000(b) & 98 & 1,70 & 0,88 & & \\
\hline & 10001 ve üzeri & 29 & 1,86 & 0,86 & & \\
\hline \multirow{4}{*}{ Sosyal Risk } & $\begin{array}{l}2500-5000 \\
\text { (a)(b) }\end{array}$ & 139 & 2,06 & 0,88 & \multirow{4}{*}{12,030} & \multirow{4}{*}{0,000} \\
\hline & $5001-7500$ (a) & 89 & 1,50 & 0,65 & & \\
\hline & 7501-10000(b) & 98 & 1,55 & 0,68 & & \\
\hline & 10001 ve üzeri & 29 & 1,70 & 0,99 & & \\
\hline
\end{tabular}

Tablo 8 deki analiz sonuçlarına göre, çevrimiçi seyahat rezervasyonuna yönelik algılanan riskler katılımcıların eğitim düzeyi ve hane halkı gelir durumuna göre istatistiksel olarak anlamlı bir farklılık gösterdiği görülmektedir. Katılımcıların yaşlarına göre ise 0,05 anlamlılık düzeyinde istatistiksel açıdan anlamlı bir farklılık olmadığı tespit edilmiştir. Bu sonuçlara göre, önlisans düzeyinde eğitime sahip katılımcıların $(\bar{X}=3,48)$ performans riski algısı lisansüstü eğitime sahip katılımcılara ( $\bar{X}=2,80)$ göre, lise düzeyinde eğitime sahip katılımcıların $(\bar{X}=2,47)$ sağlık riski algılamaları da lisansüstü eğitime sahip katılımcılara $(\bar{X}=1,81)$ göre daha fazladır. Zaman riski algısı tüm eğitim seviyelerinde birbirinden anlamlı farklılık göstermekle birlikte, en yüksek zaman riski algısına sahip grup ise lise mezunlarıdır $(\overline{\mathrm{X}}$ $=2,56)$. Algilanan sosyal risk boyutunda, lise $(\bar{X}=2,26)$ ve lisans $(\bar{X}=1,95)$ düzeyinde eğitime sahip olan katılımcıların lisansüstü $(\bar{X}=1,61)$ eğitim düzeyindeki katılımcılara göre sosyal risk algılarının daha yüksek olduğu ifade edilebilir. Bu bulgulardan hareketle, eğitim düzeyi düştükçe çevrimiçi seyahat rezervasyonuna yönelik risk algısının arttığı belirtilebilir. Hane halkı gelir durumuna bakıldığında, aylık geliri daha düşük olan katılımcıların algıladıkları sağlık, zaman ve sosyal riskler yüksektir.

Tablo 9'da, çevrimiçi seyahat rezervasyonuna yönelik algılanan risklerin katılımcıların günlük ortalama internet kullanım sıklığı ve internet üzerinden rezervasyon yapma sıklığına göre anlamlı bir farklılık gösterip göstermediğine ilişkin Anova testi sonuçları yer almaktadır. 
Tablo 9. Çevrimiçi Seyahat Rezervasyonuna Yönelik Algılanan Risklerin Günlük Ortalama İnternet Kullanım Sıklığı ve İnternet Üzerinden Rezervasyon Yapma Sıklığına Göre Karşılaştırılması

\begin{tabular}{|c|c|c|c|c|c|c|}
\hline Faktör & Değişkenler & $\begin{array}{l}\text { Sayı } \\
(\mathbf{N})\end{array}$ & $\begin{array}{c}\text { Aritmetik } \\
\text { Ortalama }(\bar{X})\end{array}$ & $\begin{array}{c}\text { Standart Sapma } \\
\text { (S.S.) }\end{array}$ & $\begin{array}{c}\text { F- } \\
\text { Değeri }\end{array}$ & $\begin{array}{c}\text { p- } \\
\text { Değeri }\end{array}$ \\
\hline \multirow{5}{*}{$\begin{array}{l}\text { Performans } \\
\text { Riski }\end{array}$} & 1 saatten az (a) & 15 & 3,46 & 0,94 & \multirow{5}{*}{2,947} & \multirow{5}{*}{0,020} \\
\hline & $1-3$ saat & 125 & 2,98 & 1,05 & & \\
\hline & 4-6 saat & 135 & 2,95 & 0,93 & & \\
\hline & 7-9 saat (a) & 58 & 2,60 & 0,81 & & \\
\hline & 10 saat ve daha fazla & 22 & 2,81 & 1,10 & & \\
\hline \multirow{5}{*}{ Sağlık Riski } & 1 saatten az (a) & 15 & 2,43 & 1,00 & \multirow{5}{*}{3,606} & \multirow{5}{*}{0,007} \\
\hline & 1-3 saat (a) & 125 & 1,79 & 0,71 & & \\
\hline & 4-6 saat & 135 & 2,05 & 0,91 & & \\
\hline & $7-9$ saat & 58 & 1,85 & 0,73 & & \\
\hline & 10 saat ve daha fazla & 22 & 1,73 & 0,66 & & \\
\hline \multirow{5}{*}{ Sosyal Risk } & 1 saatten az & 15 & 2,04 & 1,04 & \multirow{5}{*}{3,591} & \multirow{5}{*}{0,007} \\
\hline & 1-3 saat (a) & 125 & 1,56 & 0,68 & & \\
\hline & 4-6 saat (a) & 135 & 1,91 & 0,95 & & \\
\hline & $7-9$ saat & 58 & 1,74 & 0,64 & & \\
\hline & 10 saat ve daha fazla & 22 & 1,71 & 0,83 & & \\
\hline \multirow{4}{*}{ Güvenlik Riski } & Yilda 1 defa (a) (b) & 41 & 3,73 & 1,04 & \multirow{4}{*}{6,885} & \multirow{4}{*}{0,000} \\
\hline & Y1lda 2-3 defa & 115 & 3,41 & 1,01 & & \\
\hline & Yilda 4-5 defa (a) & 79 & 3,08 & 0,92 & & \\
\hline & $\begin{array}{l}\text { Yilda } 6 \text { defa ve daha } \\
\text { fazla (b) }\end{array}$ & 91 & 3,00 & 1,01 & & \\
\hline \multirow{4}{*}{$\begin{array}{l}\text { Performans } \\
\text { Riski }\end{array}$} & Yilda 1 defa (a) & 41 & 3,22 & 1,01 & \multirow{4}{*}{8,265} & \multirow{4}{*}{0,000} \\
\hline & Y1lda 2-3 defa (b) & 115 & 3,05 & 0,92 & & \\
\hline & Y1lda 4-5 defa & 79 & 2,75 & 0,91 & & \\
\hline & $\begin{array}{l}\text { Yilda } 6 \text { defa ve daha } \\
\text { fazla (a) (b) }\end{array}$ & 91 & 2,50 & 0,95 & & \\
\hline \multirow{4}{*}{ Sağlık Riski } & Yilda 1 defa (a) & 41 & 2,21 & 0,92 & \multirow{4}{*}{4,279} & \multirow{4}{*}{0,006} \\
\hline & Y1lda 2-3 defa & 115 & 1,92 & 0,83 & & \\
\hline & Y1lda 4-5 defa & 79 & 1,89 & 0,78 & & \\
\hline & $\begin{array}{l}\text { Yilda } 6 \text { defa ve daha } \\
\text { fazla (a) }\end{array}$ & 91 & 1,68 & 0,73 & & \\
\hline \multirow{4}{*}{ Sosyal Risk } & Yilda 1 defa (a) & 41 & 2,04 & 1,04 & \multirow{4}{*}{3,504} & \multirow{4}{*}{0,016} \\
\hline & Yilda 2-3 defa & 115 & 1,71 & 0,76 & & \\
\hline & Yilda 4-5 defa & 79 & 1,79 & 0,93 & & \\
\hline & $\begin{array}{l}\text { Y1lda } 6 \text { defa ve daha } \\
\text { fazla (a) }\end{array}$ & 91 & 1,55 & 0,68 & & \\
\hline
\end{tabular}

Tablo 9'daki sonuçlara göre, günlük ortalama internet kullanım sıklığı 1 saatten az $(\bar{X}=3,46)$ olan katılımcılarla 79 saat $(\bar{X}=2,60)$ günlük ortalama internet kullanım sıklığına sahip katılımcıların performans riski algısı arasında anlamlı bir fark olduğu görülmektedir. Günlük ortalama internet kullanım sıklığı 1 saatten az $(\bar{X}=2,43)$ olan katılımcılarla 1-3 saat $(\bar{X}=1,79)$ arasında olan katılımcıların sağlık riski algılamaları da anlamlı bir farklılık göstermektedir. Ayrıca, günlük ortalama internet kullanım sıklığ 4-6 saat $(\bar{X}=1,91)$ katılımcıların 1-3 saat $(\bar{X}=1,56)$ olan katılımcılara göre çevrimiçi seyahat rezervasyonuna yönelik sosyal risk algılarının farklılaştığı ve yüksek olduğu dikkat çekmektedir. İnternet üzerinden rezervasyon yapma sıklığına göre, yılda bir defa internet üzerinden seyahat rezervasyonu yaptıranların risk algılarının diğer katılımcılara göre daha yüksek olduğu, internet üzerinden daha fazla rezervasyon yapan katılımcıların risk algılarının daha düşük olduğu görülmektedir.

\subsection{Korelasyon Analizi}

Çevrimiçi seyahat rezervasyonuna yönelik algılanan risk boyutları ve kullanma eğilimi arasındaki ilişkinin tespiti amacıyla yapılan korelasyon analizi sonuçları Tablo 10'da yer almaktadır. 
Tablo 10. Korelasyon Analizi

\begin{tabular}{|c|c|c|c|c|c|c|}
\hline Faktörler & $\begin{array}{c}\text { Kullanma } \\
\text { Eğilimi }\end{array}$ & $\begin{array}{c}\text { Güvenlik } \\
\text { Riski }\end{array}$ & $\begin{array}{c}\text { Performans } \\
\text { Riski }\end{array}$ & Sağlık Riski & $\begin{array}{c}\text { Zaman } \\
\text { Riski }\end{array}$ & Sosyal Risk \\
\hline $\begin{array}{l}\text { Kullanma } \\
\text { Eğilimi }\end{array}$ & 1 &,$- 487 * *$ &,$- 528 * *$ &,$- 424 * *$ &,$- 350 * *$ &,$- 339 * *$ \\
\hline $\begin{array}{l}\text { Güvenlik } \\
\text { Riski }\end{array}$ & & 1 &, $575 * *$ &, $344 * *$ &, $251 * *$ &, $145^{* *}$ \\
\hline $\begin{array}{l}\text { Performans } \\
\text { Riski }\end{array}$ & & & 1 &, $395 * *$ &, $258 * *$ &, $283 * *$ \\
\hline Sağlık Riski & & & & 1 &, $689 * *$ &, $650 * *$ \\
\hline $\begin{array}{l}\text { Zaman } \\
\text { Riski }\end{array}$ & & & & & 1 &, $554 * *$ \\
\hline Sosyal Risk & & & & & & 1 \\
\hline
\end{tabular}

Tablo 10'da, Pearson korelasyon analizi sonucu elde edilen bulgulara göre, çevrimiçi seyahat rezervasyonuna yönelik algılanan risk boyutları ile kullanma eğilimi arasındaki ilişkinin negatif yönlü ve anlamlı olduğu görülmektedir $(\mathrm{p}<0,01)$. Bu bulgulardan hareketle, çevrimiçi seyahat rezervasyonuna yönelik algılanan riskler arttıkça katılımcıların kullanma eğilimlerinin azaldığını ifade etmek mümkündür. Algılanan performans riski $(r=-, 528)$ ile kullanma eğilimi arasında orta düzeyde negatif yönlü bir ilişki bulunmaktayken, algılanan güvenlik riski (r=-,487), sağlık riski (r=-,424), zaman riski (r=-,350) ve sosyal risk (r=-,339) arasında ise negatif yönlü zayıf bir ilişki olduğu tespit edilmiştir.

\subsection{Regresyon Analizi}

Çevrimiçi seyahat rezervasyonuna yönelik algılanan risklerin kullanma eğilimi üzerine olası etkilerini tespit etmek amacıyla regresyon analizi gerçekleştirilmiştir (Tablo 11).

Tablo 11. Regresyon Analizi

\begin{tabular}{|c|c|c|c|c|c|c|c|}
\hline & Beta & $\begin{array}{c}\text { Standart } \\
\text { Hata }\end{array}$ & $\mathbf{t}$ & $\mathbf{p}$ & VIF & $\begin{array}{c}\text { Düzeltilmiş } \\
\mathbf{R}^{2} \\
\end{array}$ & ANOVA \\
\hline Sabit & 5,844 & 0,153 & 38,132 & $0,000^{*}$ & & \multirow{6}{*}{0,375} & \multirow{6}{*}{$\begin{array}{c}\mathrm{F}=43,422 \\
\mathrm{P}=0,000\end{array}$} \\
\hline $\begin{array}{l}\text { Güvenlik } \\
\text { Riski }\end{array}$ & $-0,225$ & 0,048 & $-4,726$ & $0,000 *$ & 1,574 & & \\
\hline $\begin{array}{l}\text { Performans } \\
\text { Riski }\end{array}$ & $-0,279$ & 0,051 & $-5,511$ & $0,000 *$ & 1,625 & & \\
\hline Sağlık Riski & $-0,098$ & 0,077 & $-1,274$ & 0,203 & 2,613 & & \\
\hline $\begin{array}{l}\text { Zaman } \\
\text { Riski }\end{array}$ & $-0,091$ & 0,061 & $-1,488$ & 0,138 & 1,990 & & \\
\hline Sosyal Risk & $-0,128$ & 0,064 & $-1,995$ & 0,047 & 1,848 & & \\
\hline
\end{tabular}

$* \mathbf{p}<0,05, \mathbf{R}^{2}=\mathbf{0 , 3 8 4}$

Yapılan regresyon analizinde öncelikle bağımsız değişkenler arasında çoklu doğrusal bağlantı probleminin olup olmadığı incelenmiştir. Bunun tespiti için belirleyici olan unsurlar varyans büyütme faktörü (VIF) ve $\mathrm{R}^{2}$ değerleridir. VIF değerinin $\leq 10$ olması ve/veya $\mathrm{R}^{2} \leq 0,90$ olması çoklu doğrusal bağlantı probleminin olduğunu göstermektedir (Hair Jr. vd. 2014, 200; Albayrak 2005, 114; Vupa ve Gürünlü Alma, 2008, 99). Tablo 11'deki VIF ve R² değerleri, algılanan risk boyutlarına ilişkin çoklu doğrusal bağlantı probleminin olmadığını göstermektedir.

Tablo 11'deki bulgular, değişkenler arasındaki çoklu doğrusal regresyon modelinin anlamlı olduğunu göstermektedir $(F=43,422 ; p<0,01)$. Düzeltilmiş $\mathrm{R}^{2}$ değerine göre, algılanan risk faktörleri kullanma eğiliminin \%37,5'ini açıklamaktadır. Bununla birlikte, algılanan güvenlik riski $(\beta=-0,225 ; p<0,01)$, performans riski $(\beta=-0,279 ; p<0,01)$ ve sosyal risk $(\beta=-0,128 ; p<0,05)$ faktörlerinin, çevrimiçi seyahat rezervasyonunu kullanma eğilimi üzerinde anlamlı ve olumsuz etkilerinin olduğu görülmektedir. Buna karşılık, algılanan sağlık ve zaman riski faktörlerinin kullanma eğilimi üzerinde anlamlı bir etkiye sahip olmadığı görülmektedir ( $\mathrm{p}>0,05)$. Dolayısıyla, $\mathrm{H}_{1}, \mathrm{H}_{2}$ ve $\mathrm{H}_{5}$ kabul edilirken, $\mathrm{H}_{3}$ ve $\mathrm{H}_{4}$ reddedilmiştir. Ayrıca analiz sonuçlarına göre, katılımcıların çevrimiçi seyahat rezervasyonunu kullanma eğilimi üzerinde etkili en önemli faktörlerin sırasıyla performans riski $(\mathrm{t}=-5,511)$, güvenlik riski $(\mathrm{t}=-4,726)$ ve sosyal risk $(\mathrm{t}=-1,995)$ olduğu görülmektedir. 


\section{Tartışma}

Çevrimiçi seyahat rezervasyonu, gelişen internet teknolojileri ile birlikte son zamanlarda kişiler arasında kullanımı hızla yaygınlaşan önemli rezervasyon araçlarından biri olarak görülmektedir. Seyahat ve turizm endüstrisinde faaliyet gösteren işletmelerin kendi internet siteleri, rezervasyon web siteleri ve çeşitli mobil uygulamalar aracılı̆̆ ile kullanılan çevrimiçi seyahat rezervasyonu, hızlı ve kolay erişilebilir olması açısından kişilere önemli avantajlar sunmaktadır. Buna karşın, çevrimiçi ortamda algılanan bazı risk unsurları kişilerin çevrimiçi seyahat rezervasyonunu kullanma eğilimi üzerinde etkili olabilmektedir. Bu bağlamda, çevrimiçi seyahat rezervasyonuna yönelik algılanan risklerin kullanma eğilimi üzerine olası etkilerinin tespiti bu araştırmanın temel amacını oluşturmuş, bununla birlikte algılanan risklerin katılımcıların sosyo-demografik ve çevrimiçi seyahat rezervasyonunu kullanımına ilişkin özelliklerine göre farklılaşıp farklılaşmadığının tespitine yönelik analizler gerçekleştirilmiştir.

Betimleyici analizler sonucu elde edilen bulgular, katılımcıların büyük bir çoğunluğunun $(\% 91,8)$ daha önce çevrimiçi seyahat rezervasyonu yaptırdığını, yılda 2-3 defa $(\% 32,4)$ ve yılda 6 defa ve üzeri $(\% 25,6)$ çevrimiçi seyahat rezervasyonu yaptıranların çoğunlukta olduğunu göstermektedir. Bu veriler, ilgili alanyazında (Ling, Guo ve Yang 2014, 234; Guo vd. 2014, 104) çevrimiçi seyahat rezervasyonunun çok sayıda kişi tarafından sıklıkla kullanılan bir rezervasyon yöntemi olduğunu vurgulayan çalışmaları destekler niteliktedir. Bununla birlikte, katılımcıların çevrimiçi seyahat rezervasyonunu en çok otobüs bileti $(\% 84,5)$, uçak bileti $(\% 71,5)$ ve otel $(\% 71,3)$ rezervasyonu için kullandikları, çevrimiçi seyahat rezervasyonu yaptırırken en önemli bilgi kaynaklarının ise arkadaşlar $(\% 47,3)$ ve internet $(\% 46,8)$ siteleri olduğu görülmektedir. İnternet ortamında yapılan kullanıcı yorumlarını okuma ve hizmetler hakkında detaylı bilgi edinebilme özellikleri, kişiler için çevrimiçi rezervasyonda interneti önemli bir bilgi kaynağı durumuna getirmekte (Keskinkılıç, Ağca ve Karaman 2016, 460), yakın çevredeki arkadaş tavsiyeleri de çevrimiçi rezervasyon yapma kararı almada etkili bir faktör olarak ortaya çıkmaktadır.

Faktör analizi sonucunda, çevrimiçi seyahat rezervasyonuna yönelik algılanan risklerin güvenlik, performans, sağlık, zaman ve sosyal riskler olmak üzere toplam 5 boyuttan oluştuğu görülmektedir. Kişisel bilgilerin gönderilmesinde internetin tehlikeli bir ortam olması, güvenli olmaması, kredi kartı bilgilerinin çalınması riskinin yüksek olması ve çevrimiçi ortamda satın alınan seyahat hizmetinin vaad edilen performansı göstermesine yönelik duyulan endişeler katılımcılar tarafından yüksek düzeyde onay gören algılanan risk ifadeleridir. Hayran, Gül ve Duru $(2017,52)$ tarafından yapılan çalışmada, katılımcıların internetten en çok almayı düşündükleri ürünlerin seyahat ürünleri (uçak, tren, otobüs, vb. bileti) olduğu ortaya konulmakta, bununla birlikte hizmetlerin vaad edildiği gibi olmaması, finansal ve kişisel bilgilerin güvenliğine yönelik endişeler en nemli risk unsurları olarak tespit edilmiştir. Buradan, bu iki çalışmanın sonuçlarının benzerlik gösterdiği, elde edilen sonuçların birbirini destekler nitelikte olduğu dikkat çekmektedir. Bu sebeple, vaad edilen hizmetlerin performansının beklentileri karşılamasının sağlanması, çevrimiçi seyahat rezervasyonuna yönelik finansal ve kişisel bilgilerin güvenliğine ilişkin risklerin ortadan kaldırılması, önemle üzerinde durulması gereken hususlar olarak görülmektedir.

Araştırma kapsamında gerçekleştirilen t testi ve Anova testi sonuçları, çevrimiçi seyahat rezervasyonuna yönelik algılanan risklerin katılımcıların sosyo-demografik ve çevrimiçi seyahat rezervasyonu kullanım özelliklerine göre bazı boyutlarda farklılaştığını göstermektedir. Erkek ve evli katılımcıların sosyal risk algıları daha yüksek iken, memurların tüm boyutlardaki risk algılamaları akademisyenlere göre daha yüksek düzeydedir. Katılımcıların yaşlarına göre anlamlı bir farklılık bulunmazken, daha düşük eğitim seviyesine sahip katılımcıların tüm boyutlardaki risk algılarının daha yüksek olduğu, bununla birlikte, katılımcıların aylık hane halkı gelir düzeyi düştükçe sağlık, zaman ve sosyal risk algılarının $\operatorname{arttığı~sonucuna~ulaşılmıştır.~Bu~sonuç,~çevrimiçi~uçak~bileti~satın~almaya~yönelik~algılanan~riskleri~inceleyen~Kim,~Qu~}$ ve $\operatorname{Kim}(2009,215-216)$ tarafından yapılan, daha düşük gelir seviyesine sahip kişilerin risk algılarının daha yüksek olduğu sonucuna ulaşılan araştırmanın sonuçlarıyla tutarlılık göstermektedir. Ayrıca, eğitim düzeyi düştükçe çevrimiçi seyahat rezervasyonu hakkında daha az bilgi sahibi olunması ve buna bağlı olarak algılanan risk düzeyinin artması bu durumun olası nedenlerinden biri olarak değerlendirilebilir.

Anova testi sonucu elde edilen diğer bulgular, günlük ortalama internet kullanım sıklığı daha fazla olan katılımcıların performans ve sağlık riski algılarının daha düşük, sosyal risk algılarının ise daha yüksek olduğunu göstermektedir. Ayrıca, internet üzerinden daha sık rezervasyon yapan katılımcıların risk algılarının tüm boyutlarda daha düşük olduğu görülmektedir. Bu sonuç, gerçekleştirdikleri bir araştırmada, çevrimiçi rezervasyon yapma sıklığı ve internet kullanım süresi daha az olan kişilerin risk algılamalarının daha yüksek olduğu sonucuna ulaşan Kim, Qu ve Kim'in (2009, 212 216) bulgularıyla tutarlılık göstermektedir. İnterneti daha sık kullanan kişilerin çevrimiçi seyahat rezervasyonuna yönelik tutumlarının daha olumlu olması ve çevrimiçi seyahat rezervasyonunu daha sık kullanması şeklinde bu durumu yorumlamak mümkündür.

Gerçekleştirilen korelasyon analizi sonucu, çevrimiçi seyahat rezervasyonuna yönelik algılanan risk boyutları ile kullanma eğilimi arasında olumsuz bir ilişkinin olduğu tespit edilmiştir. Algılanan riskler arttıkça kullanma eğiliminin azaldığ kişilerin çevrimiçi seyahat rezervasyonunu kullanma eğilimlerini azaltması önemli bir sorun olarak değerlendirilebilir. Regresyon analizi sonuçlarına bakıldığında, algılanan risklerin kullanma eğilimi üzerindeki etkisi görülmekte, katılımcıların çevrimiçi seyahat rezervasyonunu kullanma eğilimi üzerinde etkili en önemli faktörlerin sırasıyla performans riski, güvenlik riski ve sosyal risk olduğu görülmektedir. Schaarschmidt ve Höber $(2017,711-712)$ tarafından çevrimiçi rezervasyona yönelik algılanan risklerin incelendiği bir diğer çalışmada, algılanan performans riskinin kullanma eğilimi üzerinde en etkili faktör olduğu ortaya konulmaktadır. Söz konusu çalışmada, hizmetlerin vaad edilen performansı 
göstermesine yönelik duyulan kaygı olarak performans riski tanımlanmaktadır. Dolayısıyla, performans riskine yönelik kaygılar kullanma eğilimini olumsuz etkileyen önemli bir faktör olarak kendini burada da göstermektedir. Çevrimiçi seyahat rezervasyonu hizmeti sunan işletmelerin bu unsuru dikkate alarak performansa yönelik algılanan riski azaltıcı tedbirler almaları önemli bir gereklilik olarak değerlendirilebilir. Nguyen ve Nguyen (2017, 1907) tarafından gerçekleştirilen bir çalışmada, algılanan risklerin çevrimiçi bankacılık hizmetlerini kullanma eğilimi üzerinde olumsuz etkiye sahip olduğu, kullanma eğilimi üzerinde en etkili faktörlerin ise güvenlik ve sosyal riskler olduğu konmaktadır. Dolayısıyla, algılanan performans riski, güvenlik riski ve sosyal risk faktörlerinin kullanma eğilimi üzerindeki olumsuz etkileri ilgili alanyazındaki benzer çalışmalar tarafından da desteklenmektedir. Kredi kartı ve kişisel bilgilerin çalınmasına dair risk algılamaları ve kişilerin arkadaş ve yakın çevrelerinden çevrimiçi seyahat rezervasyonu yapması ile ilgili eleştiriler almaları burada kullanma eğilimini olumsuz etkileyen unsurlar olarak dikkat çekmektedir. Çevrimiçi ortamda seyahat rezervasyonu hizmeti sunan işletmelerin, kişilerin özel bilgileri ve kredi kartı bilgilerinin güvenliğini artırmaya yönelik çalışmalara daha fazla önem vermeleri, kişilere hem güvenlik hem de herkes tarafından onay gören bir yöntem olarak çevrimiçi seyahat rezervasyonu hizmeti sunmaları risk algılarını azaltabilecek çözüm önerileri olarak düşünülebilir.

\section{Sonuç}

Internet ortamında, turizm işletmelerinin kendilerine ait internet sitelerini, aracı rezervasyon internet sitelerini kullanarak veya mobil rezervasyon uygulamaları üzerinden seyahat rezervasyonu yapma, son yıllarda kişiler arasında kullanımı hızla yaygınlaşan bir uygulama olarak dikkat çekmektedir. Bu araştırmadan elde edilen bulgular, kişilerin en çok otobüs bileti, uçak bileti ve otel rezervasyonu için çevrimiçi seyahat rezervasyonunu kullandıkları sonucunu ortaya çıkarmaktadır. Araba kiralama, restoran/lokanta ve gezi/tur rezervasyonunda ise çevrimiçi seyahat rezervasyonunun kullanım oranı daha düşük olarak görülmektedir. Bununla birlikte, çevrimiçi seyahat rezervasyonu yaptırma kararı almada yakın çevredeki arkadaş tavsiyeleri etkili bir faktör olarak görülmektedir. Çevrimiçi seyahat rezervasyonuna yönelik olumlu deneyimler ve tavsiyeler, diğer kişilerin bu yölntemi kullanmalarında etkili bir faktör olarak ortaya çıkmaktadır.

Çevrimiçi seyahat rezervasyonuna yönelik risk algılamalarının, kişilerin demografik özellikleriyle internet ve çevrimiçi seyahat rezervasyonu kullanım sıklıklarına göre farklılaşması bu araştırmadan elde edilen diğer sonuçlar arasındadır. Erkek katılımcıların sosyal risk algıları daha fazlayken, memurların tüm boyutlardaki risk algıları akademisyenlere göre daha fazladır. Buna göre memurlar, çevrimiçi seyahat rezervasyonunu daha riskli bulmaktadırlar. Ayrıca, eğitim seviyesi ve hane halkı gelir düzeyi düştükçe, risk algısı artmaktadır. Daha yüksek eğitim seviyesi ve gelir düzeyindeki kişilerin risk algıları ise daha düşüktür. Dolayısıyla, düşük gelir düzeyi ve eğitim seviyesi, çevrimiçi seyahat rezervasyonu kullanımına yönelik risk algılarının artmasına neden olmaktadır. Araştırmadan elde edilen diğer bulgulara bakıldığında, günlük internet kullanım sıklığı azaldıkça kişilerin risk algısı artmakta, internet üzerinden daha sık rezervasyon yaptranların risk algıları daha düşük olmaktadır. Günlük hayatlarında interneti daha sık kullanan kişiler çevrimiçi seyahat rezervasyonunu daha az riskli bir yöntem olarak değerlendirmekte, daha sık rezervasyon yapanların risk algıları da azalmaktadır.

Çevrimiçi seyahat rezervasyon yönteminin yaygın kullanımına karşın, rezervasyonun gerçekleştiği internet ortamına ilişkin algılanan bazı risk unsurları, kişilerin çevrimiçi seyahat rezervasyonunu kullanma eğilimini olumsuz yönde etkilemektedir. Rezervasyon yaparken çevrimiçi ortamda kişisel bilgilerin verilmesi, özel bilgilerin işletmelerle paylaşılması, bu bilgilerin gizliliğinin korunmaşna dair kişilerde bazı endişelerin de oluştuğu görülmektedir. Ayrıca, çevrimiçi seyahat rezervasyonu yaparak satın alınan hizmetin gerçekte vaad edilen performansı gösterip göstermeyceği, bu rezervasyon yöntemini kullanma fikrinin kişilerde yarattığı gerginlik hissi, zaman kaybı ve çevredeki diğer kişiler tarafindan eleştirilme kaygıları, kullanma eğilimi üzerinde etkili diğer unsurlar olarak belirtilebilir. Bununla birlikte, çevrimiçi seyahat rezervasyonuna yönelik algılanan riskler ile kullanma eğilimi arasında ters orantılı bir ilişki söz konusudur. Dolayısıyla, kişilerin güvenlik, performans, sağlık, zaman ve sosyal risk algıları arttıkça çevrimiçi seyahat rezervasyonunu kullanma eğilimleri azalmaktadır. Başka bir ifadeyle, artan risk algılarının kullanma eğilimi üzerinde olumsuz etkiye sahip olduğunu belirtmek mümkündür. Bu araştırma sonuçları, performans, güvenlik ve sosyal risk faktörlerinin kişilerin kullanma eğilimini etkileyen en önemli risk faktörleri olduğunu göstermetkedir.

\section{Turizm Sektörü İçin Öneriler}

Çevrimiçi seyahat rezervasyonunun en çok kullanıldı̆̆ turizm işletmeleri olan otobüs firmaları, havayolu işletmeleri ve otel işletmeleri çevrimiçi rezervasyon hizmetlerini özellikle güvenlik ve performans boyutunda geliştirmeli, kişilerin algıladıkları sosyal riskleri azaltmaya yönelik tedbirler almalıdırlar. Bununla birlikte, araba kiralama, restoran ve gezi/tur işletmelerinde bu rezervasyon yöntemine daha fazla önem verilmeli, daha çok kişinin kullanmasını sağlamaya yönelik çaba gösterilmelidir. Bu işletmeler kendi internet siteleri, aracı rezervasyon internet sitelerini ya da mobil seyahat rezervasyon uygulamalarını kullanarak daha fazla kişiye ulaşabilir, satışlarını artırabilirler. Özellikle sektöre yeni giren işletmeler için çevrimiçi seyahat rezervasyonu yöntemini kullanmak düşük maliyetli ve etkili bir araç olabilir. Günlük internet kullanım sıklığı daha az olan kişilerin çevrimiçi seyahat rezervasyonunu daha fazla kullanmaları teşvik edilmeli, güvenlik, performans ve diğer algılanan risk unsurlarına ilişkin alınan tedbirler ve sunulan kolaylıklar, imkanlar hakkında bilgiler verilmelidir. Turizm işletmeleri, çevrimiçi seyahat rezervasyonuna yönelik gerekli teknik altyapıya da sahip olmalıdır. Ayrıca, internet üzerinde rezervasyonu yapılan hizmetlerle gerçekleşen hizmetlerin vaad edilen perdormansı göstermesine dikkat edilmeli, gerçek dışı bilgilerle rezervasyon ve satış yapılmamalıdır. Toplumun genelinde çevrimiçi 
seyahat rezervasyonuna yönelik önyargılı, eleştirel tutumların oluşumu engellenmeli, doğru şekilde sunulan hizmet ve uygulamalarla kolay ve etkili bir yöntem olarak kullanımı teşvik edilmelidir.

\section{8. İleri Araştırmalar İçin Öneriler}

Bu çalışmada, çevrimiçi seyahat rezervasyonuna yönelik algılanan risklerin kullanma eğilimi üzerine etkisi anket tekniği kullanılarak tespit edilmeye çalışılmıştır. Derinlemesine mülakat gibi farklı veri toplama teknikleri kullanılarak algılanan risk faktörleri tekrar incelenebilir, kullanma eğilimi üzerindeki etkili diğer aracı faktörlerin tespitine yönelik farklı bir çalışma gerçekleştirilebilir. Bu araştırma sonuçlarına göre çevrimiçi seyahat rezervasyonu kullanma eğilimi üzerinde etkili algılanan performans, güvenlik riskleri ve sosyal risklerin azaltılmasında kullanılabilecek stratejiler tüketicilerin bakış açısıyla ele alınarak araştırılabilir. Ayrıca, çevrimiçi seyahat rezervasyonu kullanımına yönelik algılanan risk unsurlarının nedenleri daha derinlemesine araştırılarak sonuçlar karşılaştırılabilir. Algılanan risklerin, kullanma eğilimi üzerine etkilerinin yanı sıra marka deneyimi ve bu hizmeti tavsiye etme üzerine etkileri de araştırılarak çalışma genişletilebilir. Bu araştırmadan elde edilen sonuçlarla birlikte, kişilerin çevrimiçi seyahat rezervasyonunu kullanmasında etkili olan motive edici faktörlerin neler olduğunun araştırılmasının da ilgili alanyazına katkı sağlayacağı düşünülmektedir. 


\section{KAYNAKÇA}

Albayrak, A. S. (2005). Çoklu Doğrusal Bağlantı Halinde Enküçük Kareler Tekniğinin Alternatifi Yanlı Tahmin Teknikleri ve Bir Uygulama. Zonguldak Karaelmas Üniversitesi Sosyal Bilimler Dergisi, 1(1), 105-126.

Amaro, S. ve Duarte, P. (2013). Onlıne Travel Purchasing: A Literature Review. Journal of Travel \& Tourism Marketing, 30, 755-785.

Balc1, A. (2009). Sosyal Bilimlerde Araştırma Yöntem, Teknik ve Illkeler. Ankara: Pegem Akademi.

Curras-Perez, R. ve Sanchez-Garcia, I. (2012). "Satisfaction and Loyalty to a Website: TheModerating Effect of Perceived Risk", EsicMarket, 141, 183-207.

Dönmez Genç, N. (2017). Turizm Sektöründe Online Rezervasyon Kalite Algısı ve Algılanan Risk Faktörlerinin İncelenmesi, İstanbul Aydın Üniversitesi Sosyal Bilimler Enstitüsü Yüksek Lisans Tezi, İstanbul.

Ercan Kalkan, M. ve Deniz, V. (2013). Risk Kavramı Üzerine. Türk Tabipleri Birliği Mesleki Săglık ve Güvenlik Dergisi, 13(48), , 43-48.

George, D. ve Mallery, P. 2016. IBM SPSS Statistics 23 Step By Step A Simple Guide and Reference.(Fourteenth Edition). New York: Routledge.

Gregersen, N. H. (2003). Risk and Religion: Toward a Theology of Risk Taking. Zygon, 38(2), 355-376.

Guo, X., Zheng, X., Ling, L. ve Yang, C. (2014). Online Coopetition Between Hotels and Online Travel Agencies: From the Perspective of Cash Back After Stay. Tourism Management Persoectives, 12, 104-112.

Hair Jr., J. F., Black, W. C., Babin, B. J., Anderson, R. E. (2014). Multivariate Data Analysis. Harlow: Pearson Education Limited.

Hayran, S., Gül, A. ve Duru, S. (2017). Türkiye'de İnternetten Alışveriş Yapan Bireylerin Risk Algılarının Cinsiyet Farklılıklarına Göre Değerlendirilmesi. Electronic Journal of Vocational Colleges, 7(3), 48-57.

Hong, Z. ve Yi, L. (2012). Research on the Influence of Perceived Risk in Consumer Online Purchasing Decision. Physics Procedia, 24(Part B), 1304-1310.

Jacoby, J. ve Kaplan, L. B. (1972). The Components of Percieved Risk. Proceedings of The Third Annual Conference of the Association for Consumer Research, 382-393.

Kalaycı, Ş. (2010). Faktör Analizi (Ed. Kalaycı, Ş.). SPSS Uygulamalı Çok Değişkenli İstatiskik Teknikleri içinde, ss. 321-331. Ankara: Asil Yayın Dağıtım.

Karamustafa, K. ve Erbaş, E. (2011). Satın Alma Karar Sürecinde Algılanan Risk: Paket Turlara Yönelik Bir Araştırma. Tüketici ve Tüketim Araştırmaları Dergisi, 3(1), 103-144.

Kayış, A. (2010). Güvenilirlik Analizi (Reliability Analysis) (Ed. Klayc1, Ş.). SPSS Uygulamalı Çok Değişkenli İstatiskik Teknikleri içinde, ss. 403-419. Ankara: Asil Yayın Dağıtım.

Keskinkılıç, M., Ağca, Y. ve Karaman, E. (2016). İnternet ve Bilgi Sistemleri Kullanımının Turizm Dağıtım Kanallarına Etkisi Üzerine Bir Uygulama. Iş̧letme Araştırmaları Dergisi, 8(4), 445-472.

Kim, L. H., Kim, D. J. ve Leong, J. K. (2005). The Effect of Perceived Risk on Purchase Intention in Purchasing Airline Tickets Online. Journal of Hospitality \& Leisure Marketing, 13(2), 33-53.

Kim, L. H., Qu, H. ve Kim, D. J. (2009). A study of Perceived Risk and Risk Reduction of Purchasing Air-Tickets Onlıne. Journal of Travel \& Tourism Marketing, 26, 203-224.

Koçoğlu, C. M. (2016). Risk Algısının Yeniden Satın Alma Davranışı Üzerindeki Etkisi: Havayolu Sektöründe Bir Araştırma, Akademik Bakış Dergisi, 57, 246-263.

Liang, X., Li, J. ve Xu, Z. (2018). The Impact of Perceived Risk on Customers' Intention to Use-An Empirical Analysis of DiDi Car-Sharing Services. Proceedings of The 18th International Conference on Electronic Business, $644-$ 653.

Lin, P.-J., Jones, E. ve Westwood, S. (2009). Perceived Risk and Risk-Relievers in Online Travel Purchase Intentions. Journal of Hospitality Marketing \& Management, 18, 782-810.

Ling, L., Guo, X. ve Yang, C. (2014). Opening the Online Marketplace: An Examination of Hotel Pricing and Travel Agency On-line Distribution of Rooms. Tourism Management, 45, 234-243.

Marafon, D. L., Basso, K., Espartel, L. B., Barcellos, M. D. ve Rech, E. (2018). Perceived Risk and İntention to Use İnternet Banking. International Journal of Bank Marketing, 36(2), 277-289.

Marriott, H. R. ve Williams, M. D. (2018). Exploring Consumers Perceived Risk and Trust for Mobile Shopping: A Theoretical Framework and Empirical Study, Journal of Retailing and Consumer Services, 42, 133-146.

Mouakket, S. ve Al-Hawari, M. A. (2012). Examining the Antecedents of E-Loyalty Intention in an Online Reservation Environment, Journal of High Technology Management Research, 23, 46-57.

Naiyi, Y. (2004). Dimensions of Consumer's Perceived Risk in Online Shopping. Journal of Electronic Science and Technology of China, 2(3), 177-182.

Nguyen, T. D. ve Nguyen, T. C. (2017). The Role of Perceived Risk on Intention to Use Online Banking in Vietnam. Proceedings of International Conference on Advances in Computing, Communications and Informatics, 19031908.

Ozansoy Çadırcı, T. ve Sağkaya Güngör, A. (2018). Çevrimiçi Satın Almalarda Tüketicinin Risk Algısı: İki Boyutlu Ürün Görüntüleme ve Artırılmış Gerçeklik (Üç Boyutlu Ürün Görüntüleme) Uygulamalarına İlişkin Bir Karşılaştırma. Kocaeli Üniversitesi Sosyal Bilimler Dergisi, 36, 53-76. 
Pehlivan, A. (2008). "Risk” Kavramından Hareketle Türkiye'deki “Sigortacıllk” Sektörü Üzerine Değüerlendirmeler. Afyon Kocatepe Üniversitesi İktisadi ve İdari Bilimler Fakültesi Dergisi, 10(1), 87-101.

Quintal, V. A., Lee, J. A. ve Soutar, G. N. (2010). Risk, Uncertainty and the Theory of Planned Behavior: A Tourism Example. Tourism Management, 31(6), 797-805.

Schaarschmidt, M. ve Höber, B. (2017). Digital Booking Services: Comparing Online With Phone Reservation Services. Journal of Services Marketing, 31(7), 704-719.

Souza, A., Silva, A. ve Barbosa, M. L. (2016). Understanding Consumers' Reluctance to Purchase Hotel Services Online: What Makes It So Risky?. Pasos, 14(5), 1253-1266.

Türk Dil Kurumu Sözlükleri, 2019. https://www.sozluk.gov.tr/, Erişim Tarihi: 20.11.2019.

Ural, A. ve Kılıç, İ. 2013. Bilimsel Araştırma Süreci ve SPSS İle Veri Analizi, Ankara: Detay Yayıncılık.

Vupa, Ö. ve Gürünlü Alma, Ö. (2008). Doğrusal Regresyon Çözümlemesinde Çoklu Bağlantı Probleminin Sapan Değer İçeren Küçük Örneklemlerde İncelenmesi. Selçuk Ünivresitesi Fen Edebiyat Fakültesi Fen Dergisi, 31, 97-107.

Yeung, R. M. W. ve Morris, J. (2006). An Empirical Study of The İmpact of Consumer Perceived Risk on Purchase Likelihood: A Modelling Approach. International Journal of Consumer Studie, 30, 294-305.

Yıldız, S. (2017). Sosyal Bilimlerde Örnekleme Sorunu: Nicel ve Nitel Paradigmalardan Örnekleme Kuramına Bütüncül Bir Bakış. Kesit Akademi Dergisi, 3(11), 421-442.

Yüce, A. (2014). Perakendecilik Sektöründe Tüketicilerin Algıladıkları Riskler: Süpermarketlerde Bir Uygulama. EKEV Akademi Dergisi, 58, 229-250.

Zhang, L., Tan, W., Xu, Y. ve Tan, G. (2012). Dimensions of Consumers' Perceived Risk and Their Influences on Online Consumers' Purchasing Behavior. Communications in Information Science and Management Engineering, 2(7), 8-14.

Zonguldak Bülent Ecevit Üniversitesi, 2019. https://w3.beun.edu.tr/, Erişim Tarihi: 20.11.2019. 